\title{
Unshrouding the Sphere from the Clouds: Towards a Comprehensive Conceptual Framework for Sustainable Employability
}

\author{
Bram P. I. Fleuren $1, *\left(\mathbb{D}\right.$, Andries de Grip ${ }^{2,3,4}$, Nicole W. H. Jansen ${ }^{5}$, IJmert Kant ${ }^{5}(\mathbb{D}$ and \\ Fred R. H. Zijlstra ${ }^{1}$ \\ 1 Department of Work-and Social Psychology, Faculty of Psychology and Neuroscience, Maastricht University, \\ Universiteitssingel 40,6229 ER Maastricht, The Netherlands; fred.zijlstra@maastrichtuniversity.nl \\ 2 Research Center for Education and the Labour Market, School of Business and Economics, Maastricht \\ University, Tongersestraat 49, 6211 LM Maastricht, The Netherlands; a.degrip@maastrichtuniversity.nl \\ 3 IZA (Institute for the Study of Labor), Schaumburg-Lippe-Straße 5-9, 53113 Bonn, Germany \\ 4 Netspar (Network for Studies on Pensions, Ageing and Retirement), Tilburg University, Warandelaan 2, \\ 5037 AB Tilburg, The Netherlands \\ 5 Department of Epidemiology, CAPHRI School for Public Health and Primary Care, Faculty of Health, \\ Medicine and Life Sciences, Maastricht University, P. Debyeplein 1, 6229 HA Maastricht, The Netherlands; \\ nicole.jansen@maastrichtuniversity.nl (N.W.H.J.); IJ.Kant@maastrichtuniversity.nl (I.K.) \\ * Correspondence: bram.fleuren@maastrichtuniversity.nl; Tel.: +31-433-88-45-01
}

Received: 9 July 2020; Accepted: 5 August 2020; Published: 7 August 2020

\begin{abstract}
Sustainable employability refers to individuals' long-term abilities to work and remain employed. Despite its societal importance in the light of aging populations and rapidly changing skill demands, sustainable employability still requires further definition and conceptualization. As such, the present paper aims to define and conceptualize sustainable employability comprehensively by reviewing existing studies on the concept. Additionally, the paper discusses and integrates sustainable employment, sustainable work, and sustainable work ability into our broad framework of sustainable employability. The resulting conceptual framework positions sustainable employability as an inherently longitudinal multidimensional individual characteristic that is the outcome of complex interactions between individual-, work- and work environmental characteristics. This framework enables researchers to identify the employment characteristics that promote sustainable employability and thereby comprise sustainable employment. Finally, the framework links to notions of person-environment fit, and job- and organizational design to create a basis for future research on sustainable employability.
\end{abstract}

Keywords: aging; health; fatigue; well-being; competence; skill gap; sustainable work

\section{Introduction}

Sustainable employability (SE) generally refers to employees' capacities to function in work and on the labor market throughout their working lives [1]. For individuals, this ability to work is essential as working provides purpose in life, financial security, and social contacts, as well as safeguards health [2] and well-being [3,4]. Similarly, to function sustainably themselves, organizations need employees who are capable of functioning on the long term as well [5]. As such, organizations are shifting the focus of their human resource management (HRM) policies and practices from strategic to sustainable HRM [6,7]. Equivalently, on the societal level, prolonging the labor participation of individual citizens fosters economic welfare [8]. However, population aging [9-11], rapid changes in technology $[12,13]$ and changes in the nature of work $[1,14]$ urgently require promoting SE while 
simultaneously complicating doing so $[15,16]$. Therefore, a thorough scientific understanding of SE and its determinants is indispensable in sustaining individual level labor participation, organizational functioning, and societal welfare.

Problematically, a comprehensive framework for SE is still missing in the literature. That is, the currently leading (i.e., most cited) definition of SE in the international literature [1], has been subject to criticisms that have yet to be resolved [17]. Other conceptualizations of SE do exist, but these seem less comprehensive yet (as elaborated on further in the present article). Consequently, the concept of SE still lacks clear meaning and results cannot be compared across studies. Additionally, studies on the topics of sustainable employment, sustainable work [18], and sustainable work ability [19] also emerge in the literature. However, how these topics relate to SE and the extent to which they can be integrated into a comprehensive framework remains unclear. Thus, further clarification is needed regarding (a) what SE is; (b) how SE relates to workers' employability, sustainable employment, sustainable work, and sustainable work ability; and (c) how it can be operationalized. To address these needs, we review existing conceptualizations of SE and integrate research on sustainability in the context of employment. Thereby, we aim to provide a comprehensive framework that enables future research on the crucial topic of SE.

Our approach of developing a framework for SE consists of four steps. First, we consider the terms 'sustainable' and 'employability' at the fundamental semantic level to formulate a basic definition of SE. Second, having a basic definition of SE as reference point, we review existing approaches to SE to identify essential elements that should be included in a comprehensive framework for SE. Third, we integrate the existing approaches into our basic definition of SE. And fourth, we consider sustainable employment, -work, and -work ability, to integrate these concepts in our conceptual framework as well. Afterwards, we discuss implications for future research and practice.

\section{Sustainable' and 'Employability}

Starting at the basic semantic level, 'sustainable employability' consists of the noun 'employability' that is to qualify as 'sustainable'. Turning to the noun first, a basic definition of employability is "capable of being employed" [20]. When the object that has this capability is the employee, employability thus refers to that individual's capability to be employed in work. Although very basic, this definition does match scientific definitions of employability. For example, de Grip et al. [21] define employability on the individual level as "the capacity and willingness of workers to remain attractive for the labor market" (p. 216). Similarly, Fugate et al. [22] refer to employability as "one's ability to identify and realize career opportunities" (p. 23). What these and more historical definitions $[23,24]$ of employability have in common, is that employability is an individual characteristic that is determined by various (internal and external) factors, and describes how well an individual is capable of being (i.e., becoming and maintaining to be) employed in work. As such, employability should capture an individual's capacity to function at work, but also on the labor market.

The adjective 'sustainable' applies to something that is "able to be used without being completely used up" [25]. In line with the substance oriented meaning of sustainability [6], this simple definition focusses on maintenance of resources despite their use. Others have proposed that maintenance is necessary, but that sustainability also implies positive development and added value for the stakeholders and the environment [26,27]. Finkbeiner, Schau, Lehmann and Traverso [27] further argue that such developments and their effects should be considered over the life cycle of the resource concerned. Similarly, the World Commission on Environment and Development [28] defines sustainable development as development that meets the needs of the present without compromising the ability of future generations to meet their own needs [29]. In sum, sustainability can be understood as the use of a resource over time, without the utility value of that resource being negatively-and preferably positively-affected by its use. 


\section{Basic Definition of SE}

Applying the aforementioned conceptualization of sustainability to the employment of individuals, a basic definition for SE can be constructed. That is, the resource that is used in the context of employment is the individual (employee), the use is the employment of that individual in work, and the individual's utility value is the extent to which the individual can be employed, or rather, their employability. In that sense, an individual's 'employability' can be defined as sustainable employability, when it is not negatively (and preferably positively) affected by that individual's employment over time. Importantly, 'employability' is parenthesized as it still broadly refers to an individual's capacity to function at work and in the labor market.

Although very basic, the aforementioned definition captures the role of time, but potentially also the added value for stakeholders and life cycle aspects of sustainability as well. First, the inherently longitudinal component of SE is explicated in the aforementioned basic definition of SE by considering an individual's 'employability' over time. As discussed later, the existing conceptualizations of SE have not yet explicated this aspect to the same extent. Second, the added value for stakeholders [26] can also be addressed with this basic definition of SE if 'employability' is conceptualized in a sufficiently broad way. That is, if 'employability' can be considered to include health and well-being, the added value for the individual as stakeholder is clear. Note that this would also be required by the longitudinal aspect of SE, as health and well-being are crucial for an individual's long-term ability to function at work and in the labor market. For employers and society as the other main stakeholders, the added value is also relatively clear. That is, employees with high SE are beneficial for employers [5] and society benefits from high employment rates [8]. Third, to cover the life cycle aspect [27] SE should ideally be considered throughout an individual's working life. Although this is theoretically desirable, it is practically almost impossible to monitor individuals throughout their working lives. As the basic definition only requires SE to pertain to specific periods within an individual's working life, there is no necessity to consider the entire working life, but the option to do so is still open. In sum, the basic definition can adequately cover both the 'sustainability' and 'employability' components of SE. Both components are specified further in the present paper.

Two theoretically important derivations can be made from our basic definition of SE. First, as SE is defined as 'employability' not being negatively-and preferably positively-affected by an individual's employment over time, a method for adequately capturing SE can be derived. That is, assuming that 'employability' can be measured, the 'sustainability' component can be captured as the change in 'employability' over time. Positive change or stability would then indicate sustainability, whereas negative change over time would indicate a lack thereof. Consequently, by relating change in 'employability' over time to individual-, work-, and work-contextual aspects, determinants of SE can be identified. Importantly, this approach requires that 'employability' can be measured in such a way that it captures an individual's ability to function in work and on the labor market comprehensively. Second, as SE is by definition an outcome of employment, a basic definition for sustainable employment as 'predictor' can be derived as well. That is, if employment conditions do not harm SE, the situation can be referred to as sustainable employment. We elaborate on to these two points after reviewing existing approaches to SE.

Proposition 1. At the most basic level, sustainable employability means that an individual's 'employability' is not negatively, and preferably positively, affected by that individual's employment over time, where...

(a) 'Employability' in the conjoint term 'sustainable employability' is an individual characteristic that should encompass an individual's ability to function at work and in the labor market.

(b) The 'sustainability' component of SE can be captured by considering the development of 'employability' over time, making SE an inherently longitudinal construct.

(c) Sustainable employment can be inferred from an individual's situation in which SE is not negatively affected by employment over time. 
(d) The main stakeholders involved (i.e., individuals, society, and potential employers) inherently benefit from $S E$.

\section{Reviewing Existing Approaches to SE}

To develop the aforementioned basic definition further, we now consider existing conceptualizations of SE to identify essential components for a comprehensive conceptualization. First, we discuss SE's most cited conceptualization (i.e., van der Klink et al.'s conceptualization [1]) that centers on capabilities, as some of the other operational conceptualizations of SE are based on it. In the context of van der Klink et al.'s definition, we then discuss the notion of person-environment fit, as it relates closely to capabilities and another conceptualization of SE by Sanders, et al. [30] which we discuss second. We then turn to a definition centering on the ability-motivation-opportunity approach, as this constitutes a particularly salient approach in the SE literature as well. Subsequently, we discuss more operational conceptualizations (some of which based on van der Klink et al.'s definition). Throughout our discussion, we strive for completeness by referencing non-internationally (e.g., Dutch) published definitions, if they underlie an internationally published conceptualization. Finally, we distinguish approaches to SE that aim to capture the construct itself from others that treat $\mathrm{SE}$ as an umbrella term. Table 1 provides an overview of the different multidimensional approaches to SE and evaluations of each approach. 
Table 1. Overview of multidimensional approaches to sustainable employability in the literature.

\begin{tabular}{|c|c|c|c|}
\hline Authors and Definition & Operationalization & Strengths & Points for Improvement \\
\hline $\begin{array}{l}\text { Van der Klink et al. [1,31]: Sustainable employability (SE) } \\
\text { means that throughout their working lives, workers can } \\
\text { achieve tangible opportunities in the form of a set of } \\
\text { capabilities. They also enjoy the necessary conditions that } \\
\text { allow them to make a valuable contribution through their } \\
\text { work, now and in the future, while safeguarding their } \\
\text { health and welfare. This requires, on the one hand, a } \\
\text { work context that facilitates this for them and on the other, } \\
\text { the attitude and motivation to exploit these opportunities }\end{array}$ & $\begin{array}{l}\text { Capabilities set [32] that describes the extent } \\
\text { to which various potentially valued aspects of } \\
\text { work are (a) important to individuals, (b) } \\
\text { present in the form of opportunities to } \\
\text { achieve them to individuals at work, and (c) } \\
\text { actually achieved by individuals }\end{array}$ & $\begin{array}{l}\text { (a) Recognizes SE as a } \\
\text { multidimensional concept } \\
\text { (b) Explicates the relevance of context } \\
\text { to SE } \\
\text { (c) Positions SE as longitudinal } \\
\text { (d) Is the most cited } \\
\text { definition available } \\
\text { (e) Is the only full definition paper that } \\
\text { is published in an international } \\
\text { peer-reviewed journal }\end{array}$ & $\begin{array}{l}\text { (a) Conflates causes and effects in the whole of } \\
\text { the definition } \\
\text { (b) Unclear what the specific indicators of SE are } \\
\text { (c) Unclear how the longitudinal component } \\
\text { should be addressed } \\
\text { (d) Unclear at which level SE should be captured } \\
\text { (i.e., is it an individual characteristic } \\
\text { or contextual) } \\
\text { (e) Does not cover non-workers }\end{array}$ \\
\hline Peters et al. [33]: Multivariate approach & $\begin{array}{l}\text { Uses the van der Klink et al. [1] definition, } \\
\text { operationalizing SE with several indicators: } \\
\text { general } \\
\text { health, general fatigue, emotional exhaustion, } \\
\text { work ability, work engagement, } \\
\text { work-home interference, job satisfaction, and } \\
\text { sickness absence }\end{array}$ & $\begin{array}{l}\text { (a) Recognizes SE as a } \\
\text { multidimensional concept } \\
\text { (b) Explicates the relevance of health } \\
\text { and well-being to SE }\end{array}$ & $\begin{array}{l}\text { (a) Includes the behavior of sickness absence as } \\
\text { indicator (should be an outcome) } \\
\text { (b) Includes the contextual aspect of work-home } \\
\text { interference as indicator (should be } \\
\text { a predictor) } \\
\text { (c) Longitudinal aspect is ignored }\end{array}$ \\
\hline Brouwers et al. [34]: Vitality Scan & $\begin{array}{l}\text { Uses the van der Klink et al. [1] definition, } \\
\text { operationalizing SE with several indicators: } \\
\text { balance and competence, motivation and } \\
\text { involvement, resilience, mental and physical } \\
\text { health, and social support at work. }\end{array}$ & $\begin{array}{l}\text { (a) Recognizes SE as a } \\
\text { multidimensional concept } \\
\text { (b) Explicates the relevance of } \\
\text { competences, motivation, health, } \\
\text { and well-being }\end{array}$ & $\begin{array}{l}\text { (a) Dimensions included in the vitality scan are } \\
\text { data-driven based on a suboptimal use of } \\
\text { Principal Components Analyses } \\
\text { (b) Includes contextual components as indicators } \\
\text { of SE } \\
\text { (c) Includes indicators that lack clear definitions } \\
\text { (d) Conflates causes and effects as indicators } \\
\text { (e) Does not specify the longitudinal component } \\
\text { of SE }\end{array}$ \\
\hline $\begin{array}{l}\text { Sanders, Dorenbosch and Blonk [30]: A constant match } \\
\text { between what a worker is able and willing to do and } \\
\text { what the work demands and provides }\end{array}$ & $\begin{array}{l}\text { Skills and motivation maintenance via } \\
\text { lifelong learning, job (re)design, and job } \\
\text { mobility }\end{array}$ & $\begin{array}{l}\text { (a) Positions SE as longitudinal } \\
\text { (b) Recognizes SE as a } \\
\text { multidimensional concept } \\
\text { (c) Explicates the importance of skills } \\
\text { and motivation for SE } \\
\text { (d) Explicates the relevance of context } \\
\text { and employment conditions to SE }\end{array}$ & $\begin{array}{l}\text { (a) Insufficiently clarifies indicators } \\
\text { (b) Does not address the health component that is } \\
\text { crucial to long term functioning } \\
\text { (c) Does not incorporate fluctuating labor } \\
\text { market demands } \\
\text { (d) Does not cover non-workers }\end{array}$ \\
\hline
\end{tabular}


Table 1. Cont.

\begin{tabular}{|c|c|c|c|}
\hline Authors and Definition & Operationalization & Strengths & Points for Improvement \\
\hline $\begin{array}{l}\text { van Vuuren et al. [35], van Vuuren [36], Le Blanc et al. [37]: } \\
\text { The degree to which an employee is willing and able to } \\
\text { carry out his/her current and future work }\end{array}$ & $\begin{array}{l}\text { Ability Motivation Opportunity } \\
\text { framework [37] with perceived ability and } \\
\text { motivation to work until retirement, and } \\
\text { perceived employability as indicators of SE. }\end{array}$ & $\begin{array}{l}\text { (a) Uses specific indicators for SE } \\
\text { (b) Positions SE as multidimensional } \\
\text { (c) Mentions current and future work }\end{array}$ & $\begin{array}{l}\text { (a) Does not incorporate a longitudinal aspect } \\
\text { (b) Unclear about the role of context (i.e., } \\
\text { opportunity suggests context, but the } \\
\text { operationalization is perceived employability) } \\
\text { (c) Does not incorporate health } \\
\text { (d) Does not cover non-employees }\end{array}$ \\
\hline $\begin{array}{l}\text { Ybema et al. [38]: Prolonging the working life in good } \\
\text { health, while maintaining good work productivity }\end{array}$ & $\begin{array}{l}\text { Transitions in employment } \\
\text { status (e.g., the transition from employment } \\
\text { to retirement or unemployment) and } \\
\text { how productive individuals are in their paid } \\
\text { job. }\end{array}$ & $\begin{array}{l}\text { (a) Frames two relevant indicators } \\
\text { for SE } \\
\text { (b) 'Maintaining' suggests a } \\
\text { longitudinal perspective } \\
\text { (c) Positions SE as multidimensional }\end{array}$ & $\begin{array}{l}\text { (a) Transitions in employment are not } \\
\text { unambiguous indicators of SE } \\
\text { (b) Health is not actually used as indicator } \\
\text { (c) Misses out on skills and motivation as } \\
\text { key aspects } \\
\text { (d) The role of context and the labor market } \\
\text { remain unclear }\end{array}$ \\
\hline $\begin{array}{l}\text { van Harten [39]: An employee's up-to-date expertise and } \\
\text { willingness to change-i.e., current employability-and } \\
\text { [their] beliefs regarding employment opportunities. }\end{array}$ & $\begin{array}{l}\text { Up-to-date expertise, willingness to change, } \\
\text { and employment opportunities }\end{array}$ & $\begin{array}{l}\text { (a) Recognizes the role of } \\
\text { employability and skills } \\
\text { (b) Positions SE as multidimensional }\end{array}$ & $\begin{array}{l}\text { (a) Ignores the longitudinal aspect } \\
\text { (b) Does not include important indicators in the } \\
\text { health and well-being domains } \\
\text { (c) Does not cover non-employees } \\
\text { (d) The role of context could be clearer }\end{array}$ \\
\hline
\end{tabular}




\subsection{The Capability Approach}

The most widely cited and comprehensive conceptualization of SE stems from a Dutch paper [31] and was internationally published by van der Klink et al. [1] (p. 74):

"Sustainable employability means that throughout their working lives, workers can achieve tangible opportunities in the form of a set of capabilities. They also enjoy the necessary conditions that allow them to make a valuable contribution through their work, now and in the future, while safeguarding their health and welfare. This requires, on the one hand, a work context that facilitates this for them and on the other, the attitude and motivation to exploit these opportunities."

This definition clearly considers SE as a multidimensional longitudinal construct, that is determined by- and relevant to both the employee and their employer (see Table 1 for full evaluations). However, the definition also problematically combines antecedents and consequences of SE in the construct itself. Consequently, it is not clear which aspects constitute SE and at which level it should be analyzed (i.e., individual, work, and organizational components are included in the concept itself). In line with our aforementioned basic definition, it makes most sense to treat $\mathrm{SE}$ as an individual level characteristic, as it is the individual that is employed and, thus, has a certain 'employability'. It is then most fruitful to have contextual factors that can act as potential antecedents so that predictors of SE can be identified by research. Additionally, a comprehensive conceptualization of SE should specify how its inherently longitudinal nature can be captured as well as apply to unemployed individuals (see Fleuren et al. [17] for an indepth discussion).

The complicated nature of van der Klink et al.'s definition becomes particularly apparent when considering its accompanying operationalization by Abma et al. [32]. That is, Abma et al. provide an instrument that captures SE as a set of capabilities. Similar to the definition, these capabilities combine individual-level abilities and work characteristics into an overall measure of capabilities that capture SE. For example, the capability of knowledge and skills (which is one of the indicators of SE in this instrument) comprises of three items: "How important is it to you that you can use your knowledge and skills in your work?"; "Does your work offer enough opportunities to do that?"; and "To what extent do you succeed to actually do that?" [32]. However, these items partially capture opportunities in the work-context (and how these are valued and used) rather than individual abilities. As such, capabilities as conceptualized by Abma et al. can be relevant to SE, but are more likely to cover antecedent conditions rather than indicators of the construct. That is, offering employees specific opportunities (i.e., capabilities) could improve their SE, but capabilities do likely not capture an individual's SE itself.

Importantly, capabilities relate to person-environment fit. Person-environment fit refers to the interaction between the individual characteristics and environmental characteristics [40]. In the context of work, fit can be defined at several levels (e.g., fit with the job, workgroup, organization, occupation etc. [41]) and specified in several ways (i.e., objective and subjective fit, supplementary and complementary fit [42]). Particularly the complementary facets of person-job fit seem to match with capabilities. That is, the fit between a person and their job consists of whether the person has the required abilities to meet the job demands (i.e., demands-abilities fit) and whether the job supplies resources that meet the person's needs (i.e., needs-supplies fit) [43]. The central idea here is that a high person-job fit links to positive outcomes (i.e., performance, satisfaction etc.) [44]. As capabilities cover aspects people value in work as well as to what extent they are provided and made use of, they closely resemble needs-supplies fit. In sum, person-environment fit in general, needs-supplies fit in particular, and capabilities, can all be conceived of as constituting antecedents-rather than indicators-of positive outcomes such as SE.

In conclusion, the capability approach offers interesting insights in potential antecedents and individual level indicators of SE. As argued, capabilities closely resemble person-environment fit and are feasible potential antecedents-but not indicators-of SE. When treating capabilities and person-environment fit as such, research can better identify which interacting employment 
characteristics (e.g., opportunities) predict SE. That way, no assumptions regarding what aspects people value at work and that such aspects indicate SE need to be made. Nonetheless, the other individual-level aspects van der Klink et al.'s [1,31] mention in their definition (i.e., health, welfare, and motivation) could be relevant indicators of SE. Additionally, the longitudinal nature and multidimensionality in van der Klink et al.'s [1,31] conceptualization of SE should be retained and developed further.

\subsection{A Constant Match}

Sanders, Dorenbosch and Blonk [30] define SE as a "constant match between what a worker is able and willing to do and what the work demands and provides". As such, SE could be seen as an enduring person-job fit over time. Notably and as discussed, the fit aspect matches the capability approach by van der Klink et al. [1,31]. Moreover, the notion of 'constant' includes the inherent temporal component of SE as well. Sanders, Dorenbosch and Blonk [30] further develop their framework by discussing skills and motivation as aspects central to SE. They argue that employees need to maintain the skills and motivation to sustain their likelihood of employment. Finally, these authors propose three routes for developing SE: continuous life-long learning ('development route'), designing jobs to fit workers needs and abilities ('redesign route'), and moving jobs outside or within the organization ('mobility route').

Sanders, Dorenbosch and Blonk [30] provide an approach that has several merits, but also some points for further improvement (Table 1). First, the approach recognizes the necessity of skills as an important aspect in the context of SE. That is, given changes in the nature of work, employees need to remain sufficiently skilled to remain attractive on the labor market and, thus, employable [45]. Although central to understanding SE, this notion is not explicated in most approaches to SE (as discussed further in the present paper). Second, this approach explicates the time component of SE by referring to constant fit. Similar to our basic definition, this could enable capturing SE's time aspect by monitoring fit over time. As a third merit, the routes Sanders, Dorenbosch and Blonk [30] discuss, could hint to potential employment conditions that may predict and thus facilitate SE. This is a merit of this approach, as it provides directions for research with a clear positioning of lines of inquiry.

Turning to points for development, the notion of person-job fit is better positioned as antecedent condition of SE (as argued previously). Moreover, the notion of person-job fit does not explicitly include shifts in labor market demands, which should be in some way incorporated in the notion of SE itself as well. That is, an individual with a good person-job fit expectedly typically has a high SE, but this might depend on shifts in labor market demands if their job is uncommon (e.g., highly specialized niche market jobs). Moreover, although arguably implicitly, person-job fit does not explicitly include the health component. As health is a crucial component of people's ability to remain working [46,47] and considering the absence of harm to stakeholders implied in sustainability [27], individuals' health should arguably be explicitly included in SE. Furthermore, although quite broad, the person-job fit perspective is narrow in the sense that it considers a single job, but not the organization or potential jobs in the labor market. That is, when considering employability, not the fit for one job should be considered, but the broader likelihood of obtaining a (perhaps similar level) job. Finally, as argued previously, SE should be conceptualized as an individual characteristic (i.e., the individual is the unit that is employed and thus has a certain employ-ability), whereas person-job fit (like capabilities) also includes contextual components.

\subsection{The Ability-Motivation-Opportunity Framework}

A third-arguably more operational-definition of SE relies on the Ability Motivation Opportunity (AMO) framework [37]. Building on a Dutch definition of SE as "the degree to which an employee is willing and able to carry out his/her current and future work" [35,36], Le Blanc, van der Heijden and van Vuuren [37] operationalize SE based on motivation, ability and opportunity to continue working. The authors argue that to continue working, people need to be able, motivated, and have the opportunity to do so. 
A merit of the AMO approach is that it incorporates the notion of SE as a multidimensional-largely individual-characteristic (see Table 1 for full evaluations). Problematically, however, the approach of Le Blanc, van der Heijden and van Vuuren [37] does not explicitly address the longitudinal nature of SE. That is, although their single-item measures of ability and motivation refer to the expected age until the individual can and wants to remain working, a cross-sectional approach is used. Additionally, the notion of opportunity, although operationalized in this study as perceived employability, should be considered as an antecedent rather than part of SE itself (as argued previously). Finally, in terms of the operationalization used, the scope should arguably expanded with more direct measures of health, well-being and competences to enable specific monitoring of the ability components of SE. Nonetheless, the idea of capturing individual level aspects of motivation and ability seem fruitful elements that could be incorporated in future approaches to SE.

\subsection{The Vitality Scan}

Building on van der Klink et al.'s conceptualization, Brouwers, Engels, Heerkens and van der Beek [34] provide a vitality scan to capture SE. In this scan, SE is operationalized with five dimensions: balance and competence, motivation and involvement, resilience, mental and physical health, and social support at work. Notably, the dimensions motivation (and involvement), and mental and physical health agree with the aforementioned conceptualizations, but balance, resilience, and social support are novel. The vitality scan's ultimate structure results from a Principal Components Analysis (PCA) on a large set of items, by which a set of components is identified from the data. These components are then assigned meaning by the researchers to achieve the parsimonious set of dimensions as described by the authors.

The approach used in creating the vitality scan has some merits, but features several drawbacks as well (Table 1). First, although the dimensions of motivation (and involvement) and mental and physical health fit well with previously discussed conceptualizations of SE, the other dimensions seem to lack clear definitions and theoretical rationales in this paper. This point for improvement flows from the use of PCA to exploratively and empirically settle on a set of dimensions for SE. That is, PCA's exploratory by nature leads some of the dimensions to be defined post-hoc based on empirical findings rather than theoretically. To then 'validate' the emergent set of dimensions, the authors calculate general Cronbach's alpha's are calculated (i.e., rather than using much more appropriate confirmatory analyses). This is problematic because components derived from a PCA are not true factors and they are purely based on optimal variance partitioning rather than any form of theory. Additionally, the low component loadings and the varied item content suggest that formative measurement models would be more appropriate (for which Cronbach's alphas are meaningless and validation is much more complicated) [48,49]. Second-aligning with previously made points about SE as an individual level construct-the dimensions 'competence and balance', resilience, and social support, are more likely to be antecedents than indicators of SE. That is, 'competence and balance' refers to an interaction between the individual and work; resilience refers to an individual's ability to cope with/adapt to change (and is thus primarily relevant in volatile contexts, but not always); and social support is by definition a contextual predictor. Although these factors can contribute to SE, they do not seem to indicate it unambiguously. Finally, the longitudinal component of SE is not specified. In conclusion, the vitality scan seems to include useful elements (i.e., the individual level indicators of health, competence and motivation), but does not capture SE comprehensively.

\subsection{A Multivariate Approach}

Also following van der Klink et al.'s definition, Peters, Engels, de Rijk and Nijhuis [33] use a broad set of indicators to capture SE. Specifically, they include general health, general fatigue, emotional exhaustion, work ability, work engagement, work-home interference, job satisfaction, and sickness absence (see Table 1 for evaluations). As such, this conceptualization also considers SE as a multidimensional individual characteristic. Moreover, in line with the basic definition of SE provided in the present paper, most aspects are indicative of an individual's ability to function at work and on 
the labor market. However, sickness absence is a behavior rather than ability, because it describes what people do in relation to their work. SE should precede such behavior, because it refers to an ability to function. Additionally, work-home interference is also not an ability and it arguably consists of both individual (i.e., demands in the home sphere) and contextual factors (i.e., demands in the work sphere). These two variables are undoubtedly relevant in the context of SE, but work-home interference seems a predictor (rather than indicator) and sickness absence can be both a predictor (i.e., not coming to work to avoid long term disability) and an outcome (i.e., a low ability to function in work would predict sickness absence). Nonetheless, the other aspects could prove useful indicators of SE. Importantly, the longitudinal aspect of SE is not specified.

\subsection{Prolonged Working Life in Good Health and Productivity}

Ybema, Geuskens, van den Heuvel, de Wind, Leijten, Joling, Blatter, Burdorf, van der Beek and Bongers [38] define SE as "prolonging working life in good health, while maintaining good work productivity" [38]. In the design of their longitudinal study, they operationalize SE by considering transitions in employment status (e.g., the transition from employment to retirement or unemployment) and individuals' productivity in their paid job (see Table 1 for evaluations). The notion of productivity as indicator of an individual's SE seems useful as productivity is an essential means by which employees can remain attractiveness to employers and thus their employability. Moreover, productivity is a form of functioning at work in the sense that an individual's ability to function should materialize in being productive at work. However, productivity is a complicated construct, particularly considering that for many current (e.g., service-based) jobs productivity is difficult to measure. In that sense, performance (i.e., employees need to be able to perform well at work to be attractive to employers) could be a more convenient concept, because it goes beyond units-produced-per-time-unit. Similarly, although transitions can be relevant, they cannot serve as unambiguous indicators of SE. That is, an individual's employment status may change without their any change in their SE (e.g., voluntary time-specific job loss). As such, this operationalization may result in an interesting study in itself, but it does not necessarily provide straightforward and fully fitting indicators of SE.

\subsection{Expertise, Willingness to Change and Beliefs}

Another conceptualization that deliberately avoids the longitudinal perspective of SE is provided by van Harten [39]. In her dissertation SE is defined as "an employee's up-to-date expertise and willingness to change-i.e., current employability-and [their] beliefs regarding employment opportunities." [39]. The value of this definition can lie in that it reiterates the relevance of competences (i.e., expertise) as well as general employability. However, the fact that this definition discounts the longitudinal aspect of employability leaves room for improvement (Table 1).

\subsection{Singular Operationalizations of SE}

Some studies do not really define SE, but operationalize it using singular measures. A first example is van Scheppingen et al. [50] who assess SE with a single item "Taken into consideration your health, do you expect that you are still able to do this work the following 5-10 years?". Similarly, Oude Hengel [51] operationalizes SE throughout her dissertation as perceived ability and willingness to remain working until the official retirement age, but also proposes to use work ability and health status as important outcome indicators. Additionally, Noben et al. [52] operationalize SE as post-intervention absenteeism. These singular measures undoubtedly constitute relevant aspects, but do not (aim to) provide a comprehensive account of SE.

\subsection{Under the SE Umbrella}

Finally, some research refers to SE in another meaning than intended here or simply as an overarching concept and/or without aiming to define and measure it. First, Watts [53] discusses SE in the context of education programs, arguing that SE should capture not only their ability to 
obtain their first job, but to be attractive to employers on the long term. Second, some studies are positioned under the umbrella of SE, but do not actually aim to measure and predict the construct itself. An example is the study by Smaliukiene [54] that considers international variations in retirement policies within the police force and military. Similarly, Tonnon, et al. [55] explore the employer's perspective on SE of construction workers. Additionally, Ybema, et al. [56] investigate HR practices aimed at promoting SE. These studies consider contextual factors that are relevant to SE, but they do not target the construct itself. Third, some studies do also not aim to capture the construct itself, but-usually convincingly-argue that their findings can be positioned in the SE framework [57-60]. The (types of) studies mentioned in this paragraph clearly have their value, but they do not seem directly relevant for achieving a comprehensive conceptualization of SE. Therefore, they are not taken into further consideration throughout the present paper.

\subsection{Conclusions Regarding Existing SE Conceptualizations}

By considering these several conceptualizations of SE, five general conclusions emerge. First, most conceptualizations are cross-sectional and those that include a longitudinal component do not clearly specify how it should be captured. Our presented basic definition has the potential to address this issue. Second, most conceptualizations of SE revolve around individual-level indicators. This is clearly desirable as the individual is the unit that can or cannot be employed and thus SE is an individual characteristic. As such, conceptualizations that do include context-level indicators should position them as antecedents (in the employment context) rather than indicators. Third, studies typically conceptualize SE as a multidimensional construct. This also seems adequate, as SE should capture an individual's ability to function at work and on the labor market and is thus a complex multifaceted construct. As such, approaches with singular indicators should likely be expanded. Fourth, most conceptualizations share similar individual-level indicators, such as health, skills/competences, perceived employability, motivation/engagement/satisfaction, work ability, and performance/productivity. As these indicators capture distinct aspects of the ability to function at work and in the labor market, they could be relevant indicators to enrich our basic definition of SE. Finally, in line with the notion of SE as outcome of employment, these individual-level indicators can also be considered as outcomes of (or at least affected by) employment. In the following paragraphs, we use these general conclusions to develop our basic definition of SE further.

Proposition 2. A comprehensive conceptualization of SE should, based on the basic definition provided in the present paper and existing conceptualizations, ...

(a) Explicitly include the temporal component of SE.

(b) Consider SE as an individual characteristic and, thus, not include contextual components in its conceptualization.

(c) Cover functioning at work and in the labor market as a multidimensional construct.

(d) Include indicators in the health (e.g., subjective health and work ability), well-being (e.g., motivation and satisfaction), and employability (e.g., perceived employability, performance, and competences) domains.

(e) Include indicators that can be considered to be outcomes of employment.

\section{Towards A Comprehensive Definition of SE}

So far, we have established a basic definition of SE as when the 'employability' of an individual is not affected negatively (and preferably positively) affected by the way in which an individual is employed over time. 'Employability' here should then correspond to an individual's ability to function at work but also in the labor market. Further, we have proposed that if this 'employability' can be captured at multiple time points, its 'sustainability' can also be captured by considering 'employability's' development over time. This development could then be linked to several aspects of an employment situation to identify the antecedents of SE that comprise sustainable employment. We now first 
turn to what exactly constitutes 'employability' in the context of SE. Second, we consider ways of capturing 'employability's' sustainability as development over time. Third, a complete definition of SE is presented by synthesizing these two elements.

\subsection{What is 'Employability' in the Context of SE?}

As touched on previously, several conceptualizations of employability exist in the literature. First, Fugate, Kinicki and Ashforth [22] provide a dispositional approach in which employability consists of a set of personality characteristics that facilitate obtaining and maintaining employment. Second, other authors use a competence based approach where employability consists of a set of skills that facilitate obtaining and maintaining employment [23,61]. Third, employability could be conceptualized as the chance of obtaining a job in the internal or external labor market [62]. Fourth, some authors have proposed to, when capturing this chance of employment, account for the labor market demand for (types of Vanhercke et al. [63]) employees within a specific sector [21]. Fifth, other authors propose using perceived employability to capture an individual's perceptions given their skills and the state of the labor market at given time $[64,65]$. Although these approaches differ slightly, employability does seem to boil down to an individual's labor market chances, be it in terms of human capital (i.e., knowledge, skills, abilities and other relevant characteristics), the skill to market it to potential employers, or the predisposition to do so (for comprehensive discussions, see Forrier et al. and Clarke $[65,66])$. This certainly seems to match part of what SE should capture, but is it sufficient?

Despite their relevance, the aforementioned existing approaches to employability are insufficient to capture SE. That is, although proposed by some authors as antecedents of employability [67], health and well-being are not included any of the approaches. However, as SE should capture the ability to function at work and in the labor market on the long term, these components should ideally be included. After all, one of the main reasons for people to stop working/retire early are health, motivation [68,69], and negative job attitudes [70,71]. Therefore, in line with the previously discussed conceptualizations of SE, the added value for stakeholders aspect of sustainability [26,27], as well as the ICF framework for functioning [1], these aspects seem essential. However, this begs the question which components should be included in a comprehensive conceptualization of SE, besides employability, health and well-being.

\subsection{Selecting $S E^{\prime}$ S Indicators}

Based on our basic conceptualization of SE so far, five criteria for indicators can be derived. First, each indicator should capture (an aspect of) an individual's ability to function at work and in the labor market. That is, they need to match the broad 'employability' aspect of SE as discussed. Second, as SE is an individual level construct, indicators should be on the individual level as well. Third, as SE is an outcome of the way in which individuals are employed, each indicator should be an outcome of- or affected by aspects of employment characteristics. Fourth, each indicator should be related to what would theoretically be outcomes of SE. As such, they should relate to long-term employment, early labor market withdrawal, and absenteeism, as one would typically expect sustainably employable employees to actually work. And fifth, indicators should not overlap conceptually to achieve a comprehensive but parsimonious conceptualization.

Following existing conceptualizations of SE and the aforementioned criteria, a set of eight distinct indicators can be identified, spanning the domains of health, well-being, and employability. That is, in the health domain work ability, (subjective) health, and fatigue fit the criteria; in the well-being domain motivation to work and job satisfaction fit the criteria; and in the employability domain employability, competences and performance all fit the criteria. Below we discuss each of these indicators briefly and we provide an overview of their relevance for SE in Table 2. Moreover, we argue that perceived employability is the most adequate type of employability to include, fatigue should be considered as short-term (i.e., need for recovery) and long-term fatigue (i.e., prolonged fatigue or exhaustion), and 
competences are here best captured as skill-gap. As such, we propose a total of nine indicators that can comprehensively capture SE.

Table 2. Overview of proposed dimensions of sustainable employability (SE) and reasons for inclusion.

\begin{tabular}{|c|c|c|}
\hline Dimension & Description & Unique Contribution \\
\hline $\begin{array}{l}\text { Perceived health } \\
\text { status }\end{array}$ & $\begin{array}{l}\text { Individual's current health perception [72]. Describes how } \\
\text { healthy an individual feels, regardless of the presence of diseases. } \\
\text { Includes subjective health complaints and complaints associated } \\
\text { with disease [73]. Can be an outcome of employment [74]. The } \\
\text { relevance of perceived health status as indicator of functioning in } \\
\text { work is well-established }[47,75-77] \text {. }\end{array}$ & $\begin{array}{l}\text { Captures health in a } \\
\text { general sense }\end{array}$ \\
\hline Work ability & $\begin{array}{l}\text { Individual's ability to (function in) work, given that individual's } \\
\text { health status and the job demands that individual faces [78,79]. } \\
\text { Indicative of functioning in work [80] and an outcome of } \\
\text { employment [81]. Predicts absenteeism [82-84], } \\
\text { unemployment [85], and early retirement [86]. }\end{array}$ & $\begin{array}{l}\text { Captures a general } \\
\text { ability to work }\end{array}$ \\
\hline Fatigue & $\begin{array}{l}\text { Occurs when an individual systematically fails to recuperate } \\
\text { over a longer period of time. Characterized by lower efficiency, } \\
\text { negative emotions, reduced interest involvement and } \\
\text { commitment, and lower levels of motivation and } \\
\text { concentration [87]. Associated with absenteeism, work } \\
\text { disability [88], performance [89], and turnover [90]. Outcome of } \\
\text { working/employment [91,92]. }\end{array}$ & $\begin{array}{l}\text { Captures severe } \\
\text { fatigue }\end{array}$ \\
\hline Need for recovery & $\begin{array}{l}\text { Individual's ability to recuperate from work-induced } \\
\text { fatigue [93,94]. Captures acute fatigue as a state. Characterized } \\
\text { by physiological responses and disturbances of mood as a result } \\
\text { of the mental and/or physical resources of an individual being } \\
\text { depleted due to effort expenditure [95]. Related to } \\
\text { functioning [96] and predicts absenteeism [97] as well as } \\
\text { turnover [98]. By definition and empirical evidence an outcome } \\
\text { of working [99,100]. }\end{array}$ & $\begin{array}{l}\text { Captures mild } \\
\text { fatigue [101]. }\end{array}$ \\
\hline Job satisfaction & $\begin{array}{l}\text { Degree to which an individual is satisfied about their job [102]. } \\
\text { Indicator of well-being [103]. Positively associated with } \\
\text { functioning [104,105]. Negatively associated with turnover [104] } \\
\text { and absenteeism [106]. By definition and empirical evidence an } \\
\text { outcome of employment [107]. }\end{array}$ & $\begin{array}{l}\text { Captures job-related } \\
\text { well-being }\end{array}$ \\
\hline $\begin{array}{l}\text { Motivation to work } \\
\text { (intensity) }\end{array}$ & $\begin{array}{l}\text { Driving force that elicits goal-directed behavior [105]. The } \\
\text { intensity of motivation reflects how strongly an individual is } \\
\text { driven to engage specific behavior }[108,109] \text {. Outcome of } \\
\text { working [110] and linked to absenteeism and employee } \\
\text { turnover [111]. }\end{array}$ & $\begin{array}{l}\text { Captures willingness } \\
\text { to work }\end{array}$ \\
\hline $\begin{array}{l}\text { Perceived } \\
\text { employability }\end{array}$ & $\begin{array}{l}\text { Individual's labor market chances based on their human capital } \\
\text { and their capacity to market it to employers [22,23,112]. Indicates } \\
\text { functioning in the labor market and affected by current } \\
\text { employment [113], and affected by labor market conditions [21]. }\end{array}$ & $\begin{array}{l}\text { Captures functioning } \\
\text { in the labor market }\end{array}$ \\
\hline Skill-gap & $\begin{array}{l}\text { Match between an individual's skills and the job's skill } \\
\text { requirements }[46,114] \text {. Skill-gap is indicative of functioning and } \\
\text { can be an outcome of employment [45]. }\end{array}$ & $\begin{array}{l}\text { Captures the } \\
\text { competence aspect }\end{array}$ \\
\hline Job performance & $\begin{array}{l}\text { Captures how well an individual succeeds in completing the } \\
\text { tasks that are part of his/her job. Directly provides an indication } \\
\text { of an individual's ability to function in work as materialized in } \\
\text { performance. Outcome of the way in which an individual is } \\
\text { employed, negatively associated with job loss and premature } \\
\text { labor market withdrawal [115]. }\end{array}$ & $\begin{array}{l}\text { Captures materialized } \\
\text { functioning in work }\end{array}$ \\
\hline
\end{tabular}

\subsection{Health Domain}

An individual's health is a relevant indicator for functioning at work [47,75], predicts absenteeism [116,117], labor market withdrawal, and can be an outcome of employment $[46,118]$. Therefore, health in general makes for an obvious candidate as component of SE. However, rather than considering objective health status (e.g., by considering absence of diseases, disorders, or disabilities), 
subjective health (e.g., how healthy does someone feel given any potential complaints) seems most appropriate as indicator of SE. That is, diseases, disorders, and disabilities may affect the functioning of individuals to different extents, are more at the extreme end of the health continuum, show little variance over time, and their prevalence may be misrepresented in the working population due to early drop-out. Additionally, diseases, disorders and disabilities are not necessarily outcomes of employment (e.g., lung cancer may be an outcome of poor working conditions (e.g., asbestos) but may as well be caused by smoking). Therefore, when considering health indicators for SE, subjective health indicators are most feasible.

Based on the aforementioned considerations and existing conceptualizations of SE, three complementary subjective health indicators can be perceived health status, work ability, and fatigue. First, perceived health status captures how healthy individual perceive themselves to be [72]. This would make a good indicator of SE as ideally health perceptions are not affected by being employed so than individuals remain sufficiently healthy to work over time [74]. Second, work ability is used in multiple conceptualizations of SE and essentially captures how able an individual is to perform their job given their physical and mental health $[78,79]$. Although work ability is related to some of the other indicators we proposed (e.g., skills are considered one of its antecedents), its measurement is clearly health oriented and does not include these other indicators [119]. Third, fatigue is characterized by physiological responses and disturbances of mood as a result of the mental and/or physical resources of an individual being depleted due to effort expenditure [87]. As such, it captures the accumulated general effects of working on an individual over time, affects how well an individual can concentrate and is motivated to engage in activities such as work. Its relevance as indicator of SE is clear [88], but fatigue has short- and long-term components [120]. Therefore, it is instrumental to distinguish short-term need for recovery and prolonged fatigue to cover the complete fatigue continuum $[93,94]$. Table 2 provides detailed descriptions of these four indicators and their suitability for SE.

\subsection{Well-Being Domain}

Well-being encompasses the psychological component of functioning at work. Following the aforementioned conceptualizations of SE two indicators in this domain seem relevant: motivation (to work) and job satisfaction (see Table 2). Job satisfaction encompasses the attitudinal component of SE and captures how satisfied an individual is with their job [102,104]. This is relevant to SE as satisfied employees are more likely to be willing and able to function at work, and low satisfaction could indicate non-sustainable employment conditions [107]. Similarly, motivation captures the willingness to work component $[108,109,121]$ that is indispensable for SE. That is, if an individual does not want to work, are they unlikely to sustain their participation on the long-term [111]. Additionally motivation results from the extent to which an individual's needs are met by employment characteristics (cf. person-job fit) [110].

\subsection{Employability Domain}

In the employability domain, three indicators appear in existing approaches to SE that relate to functioning and attractiveness to employers. First, employability as discussed previously is an important indicator. Specifically perceived employability seems suitable, as it encompasses internal (i.e., within the current organization) and external (i.e., other organizations) labor market chances [64]. Moreover, perceived employability captures fluctuating and differing labor market demand and supply, as when assessing their own employability individuals base their judgment on (their perception of) the status quo of the labor market with awareness of relevant competitors. Perceived employability thus forms an essential contribution to SE as it captures functioning in the labor market. Second, an individual's competences should be included in SE. This is complex as no general set of competences applies to all jobs. Therefore, it is probably most convenient to consider one's skill set compared to the skills their current employer values. This does not fully cover the labor market demand for skills, but it does provide a general indication of the attractiveness of an individual's skill set. Therefore, we 
propose that skill-gap could be a convenient indicator to capture the competence aspect of SE [45]. Finally, to be sustainably employable, an individual has to be able to function productively [115]. That is, they need to perform adequately at work. As such, we propose that a comprehensive approach to SE should include job performance as indicator. Table 2 elaborates on these three indicators of SE.

In conclusion, we propose that the 'employability' as an individual's ability to function at work and in the labor market component of SE can be captured with nine indicators. These nine indicators are perceived health status, work ability, need for recovery, fatigue, job satisfaction, motivation to work, perceived employability, skill-gap, and job performance.

\subsection{Capturing the Sustainability Component of SE}

As the aforementioned nine indicators allow the 'employability' component to be captured, the 'sustainability' component of SE can be captured as well. As proposed, 'employability' can be considered sustainable if it does not decline-and preferably improves-over time. This suggests that if 'employability' has a positive or zero, but not a negative, developmental trajectory across multiple time points, it is sustainable over that specific period of time. Capturing development is essentially an issue of capturing change over time. As such, several techniques may be suitable, but we propose using latent growth curve modelling (LGCM) [122] to capture 'employability's' developmental trajectory. In LGCM the intercept and slope of the 'employability' variable can be modeled as 'latent' variables that can be related to predictor- and/or outcome variables. The slope in an LGCM represents the linear (or quadratic or cubic to model non-linear growth) development over time, whereas the intercept represents the starting value of the variable (e.g., 'employability') at the first time point included. Then, relating potential predictors to the slope of 'employability' allows estimating their effects on the 'sustainability of employability', or rather, sustainable employability (SE). Thereby, the factors that promote SE can be identified, as is the goal of SE research.

\subsection{The Full Definition of SE}

With all components (i.e., a basic definition, indicators, and the sustainability aspect) covered, we can now formulate a complete definition of SE that integrates previous conceptualizations, follows suggestions for improvement, and provides clear opportunities for operationalization and measurement of all components concerned:

"Sustainable employability means that an individual's ability to function at work and in the labor market, or their 'employability', is not negatively, and preferably positively, affected by that individual's employment over time. This ability can be captured meaningfully as a combination of nine indicators (i.e., perceived health status, work ability, need for recovery, fatigue, job satisfaction, motivation to work, perceived employability, skill-gap, and job performance) that collectively describe how well an individual can be employed at different points throughout the working life."

Figure 1 depicts the corresponding conceptual model and framework for SE. As shown in the model, SE is the middle oval that represents the slope of 'employability' over three time points. In line with the definition, 'employability' is captured as a combination of the nine indicators at each time point (i.e., the rectangular shapes in the middle to right parts of the model). Additionally, the right-most oval represents the intercept, capturing the starting value of SE at $t_{0}$. Finally, the left side of the model also includes sustainable employment as conceptualized in the next, penultimate, part of this paper. 


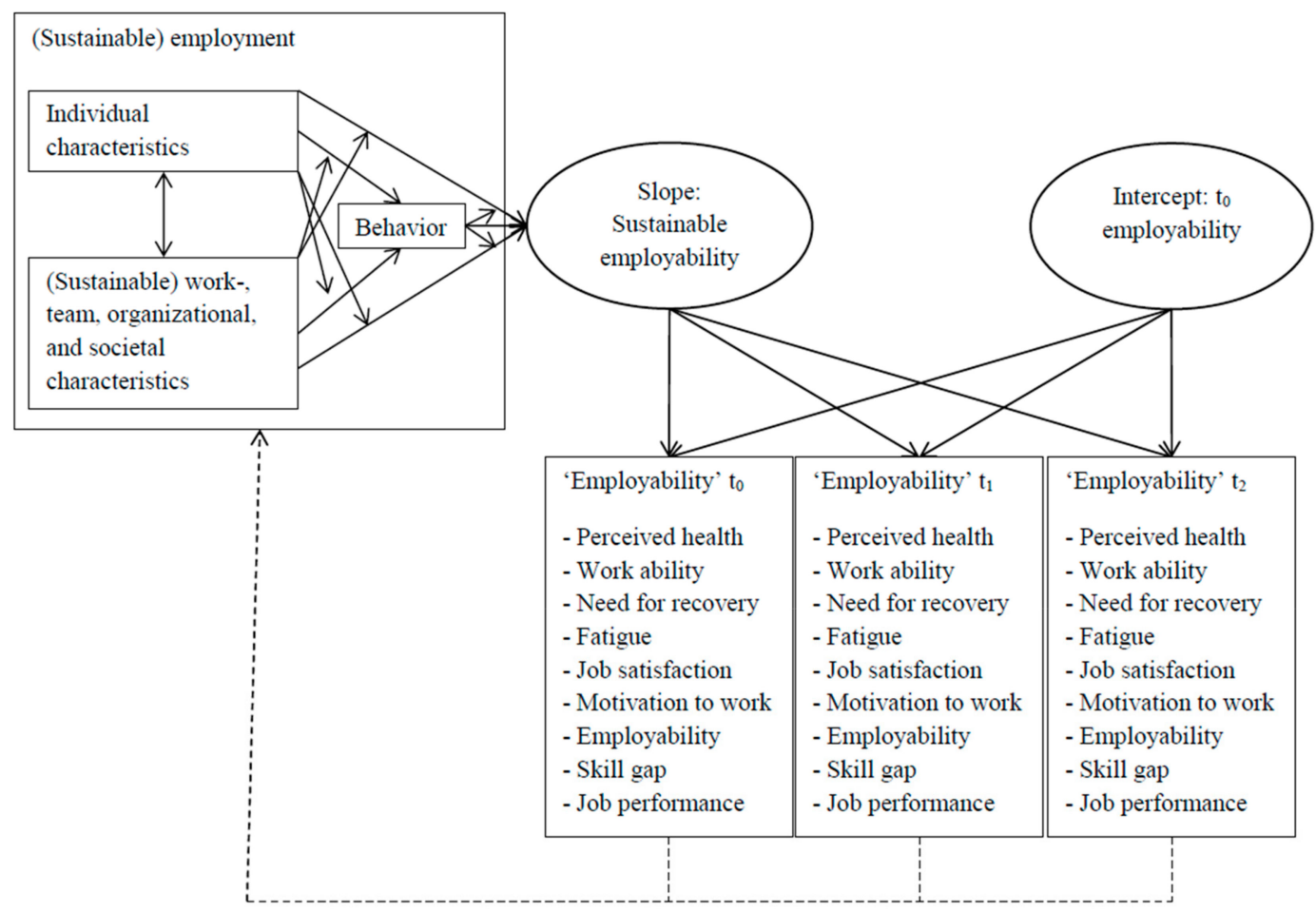

Figure 1. Complete conceptual model of sustainable employability (SE) and sustainable employment. The depicted model represents a latent growth curve model. The 'employability' component of SE is captured by nine indicators to measured at multiple points in time (here three), such that its developmental slope captures the 'sustainability'. This slope can be predicted with various interacting employment characteristics, enabling the identification of SE's predictors that together constitute sustainable employment.

\section{Sustainable Employment, Sustainable Work, and Sustainable Work Ability}

With a clear definition and operationalization of SE, we now turn to other closely related concepts of sustainable employment, -work, and -work ability. This is instrumental as these topics can be integrated into the conceptual model for SE. Moreover, it provides clarity in the literature on how these terms should be used and what they can mean.

\subsection{Conceptualizing Sustainable Employment}

As briefly mentioned previously, a definition of sustainable employment can be derived from our definition of SE. That is, sustainable employment exists when aspects of employment do not negatively affect an individual's SE over time. Consequently, employment can be referred to as sustainable by considering how aspects of an employment situation affect SE. Importantly, this definition implies that a meaningful conceptualization of (sustainable) employment should entail more than simply employment status over a specific period of time (which McCollum [123] already referred to as an "at best unambitious" (p. 216) conceptualization of sustainable employment). That is, an individual's employment status is clearly relevant for SE as the unemployed typically have lower health, well-being, and fewer opportunities to maintain competences $[45,124,125]$. However, to identify employment characteristics that are antecedents of SE-and that could thus comprise sustainable employment-employment should be conceptualized such that several individual-, work-, and work-contextual factors are considered. Consequently, sustainable employment should not only cover whether, but mainly how an individual is employed.

Employment characteristics can be identified at the individual-, work-, and work-contextual levels and include an individual's behavior. First, individuals within an employment situation have certain characteristics that form the starting position of an individual's employment (e.g., preferences, 
personality, gender, ethnicity, age [126]). Second, being employed, individuals perform tasks that can be described in terms of several work characteristics (e.g., job demands and resources). Third, individuals work in a certain environment (i.e., within a team, department, and organization, within the labor market/society [127]), that can also be described in terms of several work contextual characteristics (e.g., inclusiveness [128]). Finally, without individuals interacting with the aforementioned employment characteristics in certain ways, nothing would happen. As such, the behavior of the individual in their employment context needs to be considered as well. In sum, individual, work, and work-contextual characteristics, but also behaviors comprise an employment situation. Figure 1 synthesizes this notion of employment characteristics as interacting antecedents of SE. Sustainable in reference to employment is in brackets to represent that employment's sustainability depends on SE.

An example describing how each type of employment characteristic may relate to SE could revolve around learning at work. Consider an individual who is motivated to learn (individual characteristic), in a job that features many opportunities to learn (job/work characteristic), but an organizational climate that discourages learning (organizational characteristic). The individual, given the organizational climate, decides to not seize the opportunities (behavior) and learns less. However, given the labor market demand for highly skilled employees (societal characteristic), this has negative implications on that individual's SE (outcome). This example illustrates how SE can conceptually predicted by interactions between individual-, work-, and work-contextual characteristics and behavior that comprise the employment context. In this example, the individual is not sustainably employed, due to the organizational climate and their consequent behavior. Moreover, this example demonstrates that opportunities are predictors (rather than indicators of SE) as the extent to which they are utilized determines the individual's SE. As such, person-environment fit and capabilities, as discussed previously could constitute situations in which employment characteristics interact in a beneficial way. However, future research should show that this is actually the case.

Rather than a one-directional relationship, SE and sustainable employment likely have a reciprocal relationship. That is, as depicted by the dotted line in Figure 1, 'employability' at a certain point in time, can arguably determine employment characteristics at a later point in time. For example, if an individual does not have a sustainable employability, a change in employment characteristics (e.g., lower demands, other job, or a change in employment status) becomes increasingly likely over time. Such changes may be involuntary (e.g., job loss), but could also be deliberate. That is, when an individual notices that because of a suboptimal person-job fit (i.e., a combination of interacting individual- and job characteristics in the employment situation), their SE undergoes a negative development, they may engage in job crafting or job carving to restore the person-job fit and consequently sustain their employability over time [19].

Conceptualizing sustainable employment as a set of antecedents of SE has at least six important advantages. First, it recognizes the responsibility of employers in the context of SE. That is, van der Klink et al. [1] combined work-contextual characteristics and individual characteristics in their definition to stress the responsibility for SE of not only the employee but also the employer. Positioning sustainable employment as the (set of) antecedent(s) of SE also explicates this shared responsibility. However, and this is the second advantage, by separating employment and SE explicitly, the antecedents of SE can clearly be hypothesized and identified. Relatedly, as third advantage, SE can be recognized as an individual-level outcome of employment. It is after all the individual, who has a certain ability to be employed. Fourth, by considering employment status as an employment characteristic, this approach can also be applied to unemployed individuals. Fifth, it provides much needed clarity on the distinction between sustainable employability and sustainable employment. For example, van Dam, van Vuuren and Kemps [15] define sustainable employment as "the extent to which workers are able and willing to remain working now and in the future" (p. 2451). However, this more closely resembles typical definitions of sustainable employability rather than -employment. Sixth, our conceptualization of sustainable employment enables identifying more concrete employment aspects to intervene on than conceptualizations centering on employment status. For example, Kellard et al. [129] define 
sustainable employment as "the maintenance of a stable or upward employment trajectory in the longer term" (p. 49). Although this conceptualization captures the long-term component of sustainability, it does not offer insights in the employment aspects that may predict SE. Considering these advantages, our conceptualization of sustainable employment seems useful for research on SE.

Proposition 3. Sustainable employment describes a situation in which an individual is employed in such a way that their SE is not negatively affected over time, where...

(a) The way in which an individual is employed can describe employment status, as well as several employment characteristics.

(b) Employment characteristics can be identified at several levels including the individual's characteristics and behavior; the job/work and the tasks it consists of; the team; the organization; and the societal context.

(c) Employment characteristics can interact in several ways, potentially relating to each other as covariates (i.e., conjointly predicting SE), mediators (i.e., one characteristic's effect on SE is (partially) explained by another characteristic), and/or moderators (i.e., one characteristic's effect on SE depends on another characteristic).

(d) Person-environment fit and capabilities may constitute particularly beneficial interactions between employment characteristics.

(e) Employers and employees share the responsibility for shaping employment characteristics in such a way that they promote SE (e.g., through job design).

(f) Employment characteristics are likely partially determined by previous SE, leading to a reciprocal relationship between SE and sustainable employment over time.

\subsection{Sustainable Work and-Work Ability}

The concepts of sustainable work and sustainable work ability require clarification in the context of SE as well. These concepts are both similar and closely related to the concepts of sustainable employment and SE, but are subtly different. Moreover, both concepts can fit in our conceptual framework of SE. In the following paragraphs we discuss sustainable work and -work ability and position them in our framework. Hereby we integrate two strands of literature to facilitate future discussions and research.

Kira, van Eijnatten and Balkin [19] define sustainable work as "[work that ... ] promotes the development in employees' personal resources underlying their sustainable abilities to work" (p. 617). Similarly, Eurofound [18] suggests that "sustainable work over the life course' means that working and living conditions are such that they support people in engaging and remaining in work throughout an extended working life. These conditions enable a fit between work and the characteristics or circumstances of the individual throughout their changing life, and must be developed through policies and practices at work and outside of work" (p. 2). Additionally, Kira, van Eijnatten and Balkin [19] define sustainable work ability as "the ability to keep on working, to experience work as a positive factor in life, and to keep on making positive contributions in the lives of colleagues, customers, and other stakeholders" (pp. 627-628). This somewhat matches the 'regular' concept of work ability as discussed previously [119].

Three clear similarities between these definitions of sustainable work and work ability and our framework for sustainable employment and employability can be identified. First, both pairs of concepts of sustainable work and work ability and sustainable employment and employability intend to facilitate prolonged participation in work. As such, both pairs inherently propose a longitudinal perspective towards the functioning of employees at work (and, pertaining to the employment-employability pair, the labor market). Second, Kira, van Eijnatten and Balkin [19] clearly position sustainable work as antecedent conditions of -work ability. This predictor-outcome relationship is exactly as we propose it for sustainable employment and employability. Third, Kira, van Eijnatten and Balkin [19] argue that through collaborative work design, work can be shaped in such a way that work ability is sustained. This matches the shared responsibility employers and employees have in designing employment so that it sustains employability. Considering these three similarities, SE research may benefit from ideas on designing sustainable work as for example discussed by Kira et al. [19]. 
Important differences between sustainable work and work ability and sustainable employment and employability exist as well. The first difference is that sustainable work and work ability are slightly more narrowly defined than sustainable employment and employability. That is, the sustainable work concepts are focused on work, which is part of, but does not completely cover the conceptual bandwidth that employment is to cover. That is, sustainable employment and employability include the notion of labor market characteristics, which are essential to account for when aiming to foster participation in work [21]. Additionally, the employment conceptualization as proposed also includes individual and organizational characteristics as input variables. As such, sustainable work may be part of sustainable employment and sustainable work ability can be considered an aspect of SE. In fact, previous work on SE includes work ability as one of the key-indicators $[33,51,130]$. Second, no clear measures for sustainable work and -work ability exist and it is unclear how the time-factor should be operationalized to truly capture the sustainability aspect. Of course, the work ability index could arguably be used over time to capture sustainable work ability, but the literature has yet to propose this. Similarly, no clear indicators for sustainable work have been proposed yet, but it probably could follow the same structure as sustainable employment in our framework. That is, sustainable work could be inferred from sustainable work ability over time. Again, sustainable work and -work ability can clearly be positioned in the proposed framework and this arguably helps further their operationalizations.

In conclusion it seems that sustainable work and work ability can be placed within the sustainable employment and employability framework. Figure 1 aims to depict this by including "(Sustainable) work" as part of the conceptualization of employment. Similarly, work ability is included as one of SE's indicators. Hereby, the two separate strands of literature can be integrated and mutually beneficial lessons can be exchanged. Moreover, the similarities between the two approaches towards sustainability provide some confidence regarding their validity and viability.

Proposition 3. Sustainable work and sustainable work ability can be positioned in the framework of SE in such a way that ...

(a) Sustainable work covers one aspect of sustainable employment, namely that work characteristics are shaped in such a way that they are associated with sustainable work ability and SE.

(b) Sustainable work ability covers one aspect of SE.

\section{Discussion}

By building a fundamental semantic conceptualization of sustainable employability (SE) as well as reviewing and integrating its existing conceptualizations, the present paper provides comprehensive definitions and a conceptual framework for SE and sustainable employment. The resulting framework integrates sustainable work and sustainable work ability by Kira, van Eijnatten and Balkin [19], clarifying the connection between these concepts and SE. The presented approach, conceptualizes SE as a longitudinal multidimensional individual-level construct that is predicted by characteristics of (sustainable) employment. Sustainable employment is then conceptualized as interacting individual, work, and work-contextual characteristics that contribute to SE. As such, sustainable employment theoretically encompasses capabilities [1,32] and person-environment fit [30,44], which are positioned as potential antecedents—rather than indicators-of SE. Consequently, the framework separates cause and effect, makes SE measurable, provides a clear reference point for research on SE and sustainable employment, and, as argued, meets all requirements for a comprehensive conceptualization of SE as proposed by Fleuren et al. [17]. For practitioners and policy makers the presented conceptual framework implies that long-term multifaceted approaches are necessary to monitor and improve SE. For researchers the road towards meaningful research on SE now seems a little less bumpy.

\subsection{Implications for Research and Theory}

By conceptualizing SE as an inherently longitudinal construct, the first major implication for research and theory is that studies on SE need to be longitudinal. As sustainability can only be captured 
in longitudinal research, cross-sectional studies can theoretically not address SE. Consequently, we propose that studies on SE follow individuals over time and use analytical techniques such as latent growth curve modeling and other approaches that capture change over time and can relate it to employment characteristics. For example, researchers with two-wave data could compute difference scores to capture SE as change from one time point to the next. Additionally, the proposed conceptualization allows for considering the entire working life, but does not require it. That is, SE is ideally considered across the lifespan as early exposure to certain conditions could determine later SE [131]. However, our framework allows for studying SE across shorter timespans as well, of which future research should determine the ideal length (see Fleuren [132] for an extensive discussion). These aspects of our conceptualization provide researchers with flexibility as well as a clear criterion to establish whether studies actually capture SE.

A second implication for SE research is that there is work to do in terms of mapping the employment characteristics that may constitute sustainable employment. Arguably, this is a daunting exercise, but as sustainable employment can encompass capabilities [1] and person-environment fit [44], researchers have clear starting points. For example, aspects individuals find valuable in their work or the extent to which certain job characteristics interact with individual characteristics in constituting a good fit could be considered. Additionally, researchers may draw from previous research on quality of working life and job characteristics [133-136] the job-demands resources framework [137], and decent work [138]. Similarly, researchers could follow Hacker's [139] hierarchical work evaluation criteria to guide SE research. That is, Hacker's criteria could be used to identify employment characteristics that make work (i) executable; (ii) protective of health; (iii) protective of functioning; and (iv) contribute to personal development. These several research streams and theoretical frameworks could indicate employment characteristics that are relevant to SE. Following the proposed approach and to address societal questions pertaining to population aging [140], the effects of these characteristics should be considered longitudinally and on SE as an integral combination of its indicators.

Third, our proposed conceptualization of SE may be instrumental in other streams of research. That is, studies considering sustainability in organizations [141], sustainable human resource management [142], and sustainable work systems [143] have approached sustainability as non-exploitative utilization of (human) resources. As such, they could arguably use SE as a relevant criterion to capture the extent to which employees are 'exploited' over time. Although such broad concepts probably require multiple indicators (e.g., also incorporating effects on the environment and other stakeholders), SE may adequately cover the individual level and provide directions for clarifying sustainability in these streams of research.

Fourth, considering how the present paper-but also previous work-conceptualizes SE, it should be recognized as a social construct rather than a latent individual characteristic. That is, conceptualizing SE as a complex multi-indicator construct covering a broad conceptual domain makes it highly unlikely that SE constitutes a latent characteristic that exists in individuals. Instead SE should be considered a social construct of which the exact meaning (i.e., indicators) can be contextually dependent [48]. As such, the indicators we propose might be supplemented with- or replaced by other indicators, if additional or superior indicators for SE are identified by research. That is, the present paper argues that SE should be captured as a longitudinal multidimensional individual-level construct covering functioning at work and in the labor market, but its exact set of indicators could arguably be further developed. Regardless, we consider our current framework an important step forward in the debate on SE.

Fifth, an important theoretical point regarding SE as social construct is also its somewhat relative nature. That is, the indicators of perceived employability and skill-gap can be understood as generic, but also include an implicit connection to the context. Perceived employability namely incorporates the notions of competitors and labor market chances and skill-gap incorporates a reference to the current job. These aspects are desirable as the labor market value (and ability to function in the labor market) depend on market conditions (i.e., meeting employers' desired states of functioning, being part of a 
specific subset of actors in the labor market that compete for jobs and the availability of fitting jobs). However, it should be noted that as labor market demands for specific lines of work shift, a skill set in reference to the current job could become obsolete. Such shifts are likely particularly relevant in fast developing, narrow, or highly competitive segments of the labor market. To this end, good measures of SE incorporate both perceived employability and up-to-date measures of skill-gap. Moreover, these notions stress the relevance of considering industry-specific developments with regard to SE [21,132].

Finally, the complex multidimensional nature of SE likely requires interdisciplinary research. That is, our conceptualization of SE includes constructs from the health, well-being, and employability domains. Therefore, research projects on SE likely benefit from a team of researchers with expertise in various domains of employment-related research. For example, to capture the relationship between organizational aspects and SE, insights from HRM experts are indispensable. Similarly, as we have done for this study, it is instrumental to draw on expertise in work- and organizational psychology, occupational epidemiology, and labor economics to address the well-being, health, and employability components of SE respectively.

\subsection{Implications for HRM Practice}

Although this paper is conceptual and mainly targeted at improving the scientific understanding of SE, it does have at least two implications for practice. First, SE is positioned as a shared responsibility of the individual and their employer. As such, organizations should place promoting their employees' SE on the HR agenda. This means that HR managers need a broad understanding of what SE is and how it can be addressed. The present paper helps them in doing so. Second, SE requires a longitudinal multifaceted and individual-focused approach (see Fleuren et al. [144] for an extensive practical development oriented example). Consequently, aiming to promote SE requires longitudinal monitoring and most likely (i.e., considering person-environment fit as probable antecedent) a personalized approach to SE. As such, HR managers are required to maintain an ongoing future-oriented dialogue with employees to identify opportunities and bottlenecks in achieving SE.

Author Contributions: All authors meet requirements for authorship, with the contributions being as follows: Conceptualization: B.P.I.F., A.d.G., N.W.H.J., I.K., F.R.H.Z.; Investigation: B.P.I.F., A.d.G., N.W.H.J., I.K., F.R.H.Z.; Writing (original draft): B.P.I.F.; Writing (reviewing and editing): B.P.I.F., A.d.G., N.W.H.J., I.K., F.R.H.Z.; Visualization: B.P.I.F.; Supervision: A.d.G., N.W.H.J., I.K., F.R.H.Z.; Project administration: A.d.G., I.K., F.R.H.Z. All authors have read and agreed to the submitted version of the manuscript.

Funding: This research received no external funding.

Conflicts of Interest: The authors declare not conflict of interest.

\section{References}

1. Van der Klink, J.J.L.; Bültmann, U.; Burdorf, A.; Schaufeli, W.B.; Zijlstra, F.R.H.; Abma, F.I.; Brouwer, S.; van der Wilt, G.J. Sustainable employability—definition, conceptualization, and implications: A perspective based on the capability approach. Scand. J. Work Environ. Health 2016, 42, 71-79. [CrossRef] [PubMed]

2. Schuring, M.; Mackenbach, J.; Voorham, T.; Burdorf, A. The effect of re-employment on perceived health. J. Epidemiol. Community Health 2011, 65, 639-644. [CrossRef] [PubMed]

3. Lee, S.A.; Ju, Y.J.; Han, K.T.; Choi, J.W.; Yoon, H.J.; Park, E.C. The association between loss of work ability and depression: a focus on employment status. Int. Arch. Occup. Environ. Health 2017, 90, 109-116. [CrossRef] [PubMed]

4. Gowan, M.A. Moving from job loss to career management: the past, present, and future of involuntary job loss research. Hum. Resour. Manag. Rev. 2014, 24, 258-270. [CrossRef]

5. Hall, R. A framework linking intangible resources and capabilities to sustainable competitive advantage. Strateg. Manag. J. 1993, 14, 607-618. [CrossRef]

6. Kramar, R. Beyond strategic human resource management: is sustainable human resource management the next approach? Int. J. Hum. Resour. Manag. 2014, 25, 1069-1089. [CrossRef] 
7. Ehnert, I.; Parsa, S.; Roper, I.; Wagner, M.; Muller-Camen, M. Reporting on sustainability and HRM: A comparative study of sustainability reporting practices by the world's largest companies. Int. J. Hum. Resour. Manag. 2016, 27, 88-108. [CrossRef]

8. Jacobsen, H.J.; Schultz, C. Decreasing unemployment increases welfare. Scand. J. Econ. 1992, 94, $491-496$. [CrossRef]

9. Alemayehu, B.; Warner, K.E. The lifetime distribution of health care costs. Health Serv. Res. 2004, 39, 627-642. [CrossRef]

10. Shah, M.N.; Bazarian, J.J.; Lerner, E.B.; Fairbanks, R.J.; Barker, W.H.; Auinger, P.; Friedman, B. The epidemiology of emergency medical services use by older adults: an analysis of the National Hospital Ambulatory Medical Care Survey. Acad. Emerg. Med. 2007, 14, 441-447. [CrossRef]

11. Fisher, G.G.; Truxillo, D.M.; Finkelstein, L.M.; Wallace, L.E. Age discrimination: Potential for adverse impact and differential prediction related to age. Hum. Resour. Manag. Rev. 2017, 27, 315-327. [CrossRef]

12. Autor, D.H.; Levy, F.; Murnane, R.J. The skill content of recent technological change: An empirical exploration. Q. J. Econ. 2003, 118, 1279-1333. [CrossRef]

13. Machin, S.J.; van Reenen, J. Technology and changes in skill structure: Evidence from seven OECD countries. Q. J. Econ. 1998, 113, 1215-1244. [CrossRef]

14. Cartwright, S.; Holmes, N. The meaning of work: the challenge of regaining employee engagement and reducing cynicism. Hum. Resour. Manag. Rev. 2006, 16, 199-208. [CrossRef]

15. Van Dam, K.; van Vuuren, T.; Kemps, S. Sustainable employment: the importance of intrinsically valuable work and an age-supportive climate. Int. J. Hum. Resour. Manag. 2017, 28, 2449-2472. [CrossRef]

16. Cascio, W.F. Training trends: Macro, micro, and policy issues. Hum. Resour. Manag. Rev. 2017, in press. [CrossRef]

17. Fleuren, B.P.I.; de Grip, A.; Jansen, N.W.H.; Kant, I.; Zijlstra, F.R.H. Critical reflections on the currently leading definition of sustainable employability. Scand. J. Work Environ. Health 2016, 42, 557-560. [CrossRef]

18. Eurofound. Sustainable Work over the Life Course: Concept Paper; Publications Office of the European Union: Luxembourg, 2015. [CrossRef]

19. Kira, M.; van Eijnatten, F.M.; Balkin, D.B. Crafting sustainable work: development of personal resources. J. Organ. Chang. Manag. 2010, 23, 616-632. [CrossRef]

20. MWOD. Employability. Merriam Webster Online Dictionary. Available online: https://www.merriamwebster.com/dictionary/employability (accessed on 8 December 2018).

21. De Grip, A.; van Loo, J.; Sanders, J. The industry employability index: taking account of supply and demand characteristics. Int. Labour Rev. 2004, 14, 211-233. [CrossRef]

22. Fugate, M.; Kinicki, A.J.; Ashforth, B.E. Employability: A psycho-social construct, its dimensions, and applications. J. Vocat. Behav. 2004, 65, 14-38. [CrossRef]

23. Hillage, J.; Pollard, E. Employability: Developing a Framework for Policy Analysis; DfEE: London, UK, 1998.

24. Gazier, B. Employability - Concepts and Policies; European Employment Observatory: Berlin, Germany, 1999.

25. MWOD. Sustainable. Merriam Webster Online Dictionary. Available online: https://www.merriam-webster. com/dictionary/sustainable (accessed on 8 December 2018).

26. Newman, L. Uncertainty, innovation, and dynamic sustainable development. Sustain. Sci. Pract. Policy 2005, 1, 25-31. [CrossRef]

27. Finkbeiner, M.; Schau, E.M.; Lehmann, A.; Traverso, M. Towards life cycle sustainability assessment. Sustainability 2010, 2, 3309-3322. [CrossRef]

28. World Commission on Environment and Development, W. Our Common Future; Oxford University Press: Oxford, UK, 1987.

29. Kuhlman, T.; Farrington, J. What is sustainability? Sustainability 2010, 2, 3436-3448. [CrossRef]

30. Sanders, J.; Dorenbosch, L.; Blonk, R.W.B. The fragility of employability: A dynamic perspective and examples from the Netherlands. In Sustainable Working Lives; Vuori, J., Blonk, R.W.B., Price, R.H., Eds.; Springer: Dordrecht, The Netherlands; pp. 187-214. [CrossRef]

31. Van der Klink, J.J.L.; Brouwer, S.; Bultmann, U.; Burdof, L.; Schaufeli, W.B.; van der Wilt, G.J.; Zijlstra, F.R.H. Duurzaam Inzetbaar: Een Werkdefinitie [Sustainable Employability: A Working Definition]; ZonMw: Den Haag, The Netherlands, 2010. 
32. Abma, F.I.; Brouwer, S.; de Vries, H.J.; Arends, I.; Robroek, S.J.W.; Cuijpers, M.P.J.; van der Wilt, G.J.; Bültmann, U.; van der Klink, J.J.L. The capability set for work: development and validation of a new questionnaire. Scand. J. Work Environ. Health 2016, 42, 34-42. [CrossRef] [PubMed]

33. Peters, V.; Engels, J.A.; de Rijk, A.E.; Nijhuis, F.J.N. Sustainable employability in shiftwork: related to types of work schedule rather than age. Int. Arch. Occup. Environ. Health 2015. [CrossRef] [PubMed]

34. Brouwers, L.A.M.; Engels, J.A.; Heerkens, Y.F.; van der Beek, A.J. Development of a vitality scan related to workers' sustainable employability: A study assessing its internal consistency and construct validity. BMC Public Health 2015, 15, 511-519. [CrossRef]

35. Van Vuuren, T.; Caniëls, M.C.J.; Semeijn, J.H. Duurzame inzetbaarheid en een leven lang leren. Gedrag $\mathcal{E}$ Organisatie 2011, 24, 357-374.

36. Van Vuuren, T. Vitaliteitsmanagement: Je hoeft niet ziek te zijn om beter te worden [Vitality management: One does not need to be ill to get better!]. Gedrag \& Organisatie 2012, 25, 400-418.

37. Le Blanc, P.M.; van der Heijden, B.I.J.M.; van Vuuren, T. "I will survive": A construct validation study on the measurement of sustainable employability using different age conceptualizations. Front. Psychol 2017, 8, 1-12. [CrossRef]

38. Ybema, J.F.; Geuskens, G.A.; van den Heuvel, S.G.; de Wind, A.; Leijten, F.R.M.; Joling, C.; Blatter, B.M.; Burdorf, A.; van der Beek, A.J.; Bongers, P.M. Study on transitions in employment, ability, and motivation (STREAM): the design of a four-year longitudinal cohort study among 15,118 persons age 45 to 64 years. Br. J. Med. Med. Res. 2014, 4, 1383-1399. [CrossRef]

39. Van Harten, J. Employable Ever After: Examining the Antecedents and Outcomes of Sustainable Employability in a Hospital Context; Utrecht University: Utrecht, The Netherlands, 2016.

40. Kristof, A.L. Person-organization fit: An integrative review of its conceptualizations, measurement, and implications. Pers. Psychol. 1996, 49, 1-49. [CrossRef]

41. Jansen, K.J.; Kristof-Brown, A.L. Toward a multidimensional theory of person-environment fit. J. Manag. Issues 2006, 18, 193-212.

42. Edwards, J.R.; Cable, D.M.; Williamson, I.O.; Schurer Lambert, L.; Shipp, A.J. The phenomenology of fit: linking the person and environment to the subjective experience of person-environment fit. J. Appl. Psychol. 2006, 91, 802-827. [CrossRef] [PubMed]

43. Cable, D.M.; DeRue, D.S. The convergent and discriminant validity of subjective fit perceptions. J. Appl. Psychol. 2002, 87, 875-884. [CrossRef]

44. Kristof-Brown, A.L.; Zimmerman, R.D.; Johnson, E.C. Consequences of individuals' fit at work: A meta-analysis of person-job, person-organization, person-group, and person-supervisor fit. Pers. Psychol. 2005, 58, 281-342. [CrossRef]

45. De Grip, A.; van Loo, J. The economics of skills obsolescence: A review. In The Economics of Skills Obsolescence (Research in Labor Economics); De Grip, A., van Loo, J., Mayhew, K., Eds.; Emerald Group Publishing Limited: Bingley, UK, 2002; Volume 21, pp. 1-25.

46. De Wind, A.; Geuskens, G.A.; Ybema, J.F.; Blatter, B.M.; Burdorf, A.; Bongers, P.M.; van der Beek, A.J. Health, job characteristics, skills, and social and financial factors in relation to early retirement - results from a longitudinal study in the Netherlands. Scand. J. Work Environ. Health 2014, 40, 186-194. [CrossRef]

47. Boschman, J.S.; Hulshof, C.T.J.; Frings-Dresen, M.H.W.; Sluiter, J.K. Improving fit to work assessments for rail safety workers. Int. Arch. Occup. Environ. Health 2016, 89, 803-811. [CrossRef]

48. Fleuren, B.P.I.; van Amelsvoort, L.P.G.M.; Zijlstra, F.R.H.; de Grip, A.; Kant, I. Handling the reflective-formative measurement conundrum: A practical illustration based on sustainable employability. J. Clin. Epidemiol. 2018, in press. [CrossRef]

49. Van Amelsvoort, L.G.P.M.; Fleuren, B.P.I.; Kant, I. Improving measurement models in clinical epidemiology: time to move beyond the inherent assumption of an underlying reflective measurement model. J. Clin. Epidemiol. 2020, 118, 119-123. [CrossRef]

50. Van Scheppingen, A.R.; de Vroome, E.M.M.; ten Have, K.C.J.M.; Zwetsloot, G.I.J.M.; Wiezer, N.; van Mechelen, W. Vitality at work and its associations with lifestyle, self-determination, organizational culture, and with employees' performance and sustainable employability. Work 2015, 52, 45-55. [CrossRef]

51. Oude Hengel, K.M. Sustainable Employability of Construction Workers; Uitgeverij Buijten \& Schipperheijn: Amsterdam, The Netherlands, 2013. 
52. Noben, C.Y.G.; Nijhuis, F.J.N.; de Rijk, A.E.; Evers, S.M.A.A. Design of a trial-based economic evaluation on the cost-effectiveness of employability interventions among work disabled employees or employees at risk of work disability: The CASE-study. BMC Public Health 2012, 12. [CrossRef] [PubMed]

53. Watts, A.G. Career Development, Learning, and Employability; The Higher Education Academy: York, UK, 2006.

54. Smaliukienè, R. Towards sustainable employability: European practices in officers and servicemen reintegration after early retirement. J. Secur. Sustain. Issues 2014, 4, 17-28. [CrossRef]

55. Tonnon, S.C.; van der Veen, R.; Westerman, M.J.; Robroek, S.J.W.; van der Ploeg, H.P.; van der Beek, A.J.; Proper, K.I. The employer perspective on sustainable employability in the construction industry. J. Occup. Environ. Med. 2017, 59, 85-91. [CrossRef] [PubMed]

56. Ybema, J.F.; van Vuuren, T.; van Dam, K. HR practices for enhancing sustainable employability: implementation, use, and outcomes. Int. J. Hum. Resour. Manag. 2017, 1-22. [CrossRef]

57. Leijten, F.R.M.; van den Heuvel, S.G.; Ybema, J.F.; Robroek, S.J.W.; Burdorf, A. Do work factors modify the association between chronic health problems and sickness absence among older employees? Scand. J. Work Environ. Health 2013, 39, 477-485. [CrossRef]

58. Rongen, A.; Robroek, S.J.W.; Schaufeli, W.; Burdorf, A. The contribution of work engagement to self-perceived health, work ability, and sickness absence beyond health behaviors and work-related factors. J. Occup. Environ. Med. 2014, 56, 892-897. [CrossRef]

59. Van der Heijden, B.I.J.M.; Gorgievski, M.J.; de Lange, A.H. Learning at the workplace and sustainable employability: a multi-source model moderated by age. Eur. J. Work Organ. Psychol. 2015, 25, 13-30. [CrossRef]

60. Van Holland, B.J.; De Boer, M.R.; Brouwer, S.; Soer, R.; Reneman, M.F. Sustained employability of workers in a production environment: design of a stepped wedge trial to evaluate effectiveness and cost-benefit of the POSE program. BMC Public Health 2012, 12, 1003-1011. [CrossRef]

61. Van der Heijde, C.M.; van der Heijden, B.I.J.M. A competence-based and multidimensional operationalization and measurement of employability. Hum. Resour. Manag. 2006, 45, 449-476. [CrossRef]

62. Forrier, A.; Sels, L. The concept of employability: A complex mosaic. Int. J. Hum. Resour. Dev. Manag. 2003, 3, 102-124. [CrossRef]

63. Bowman, D.; McGann, M.; Kimberly, H.; Biggs, S. 'Rusty, invisible and threatening': Aging, capital and employability. Work Employ. Soc. 2016, 1-18. [CrossRef]

64. Vanhercke, D.; de Cuyper, N.; Peeters, E.; de Witte, H. Defining perceived employability: a psychological approach. Pers. Rev. 2014, 43, 592-605. [CrossRef]

65. Forrier, A.; Verbruggen, M.; de Cuyper, N. Integrating different notions of employability in a dynamic chain: the relationship between job transitions, movement capital and perceived employability. J. Vocat. Behav. 2015, 89, 56-64. [CrossRef]

66. Clarke, M. Understanding and managing employability in changing career contexts. J. Eur. Ind. Train. 2008, 32, 258-284. [CrossRef]

67. McQuaid, R.W.; Lindsay, C. The concept of employability. Urban. Stud. 2005, 42, 197-219. [CrossRef]

68. Feldman, D.C. The decision to retire early: a review and conceptualization. Acad. Manag. Rev. 1994, 19, 285-311. [CrossRef]

69. Shultz, K.S.; Morton, K.R.; Weckerle, J.R. The influence of push and pull factors on voluntary and involuntary early retirees' retirement decision and adjustment. J. Vocat. Behav. 1998, 53, 45-57. [CrossRef]

70. Thorsen, S.V.; Jensen, P.H.; Bjørner, J.B. Psychosocial work environment and retirement age: a prospective study of 1876 senior employees. Int. Arch. Occup. Environ. Health 2016, 891-900. [CrossRef]

71. Van Dam, K.; van der Vorst, J.D.M.; van der Heijden, B.I.J.M. Employees' intentions to retire early: a case of planned behavior and anticipated work conditions. J. Career Dev. 2009, 35, 265-289. [CrossRef]

72. Hunt, S.M.; McKenna, S.P.; McEwen, J.; Backett, E.M.; Williams, J.; Papp, E. A quantitative approach to perceived health status: a validation study. J. Epidemiol. Commun. Health 1980, 34, 281-286. [CrossRef]

73. Lind, R.; Arslan, G.; Eriksen, H.R.; Kahrs, G.; Haug, T.T.; Florvaag, E.; Berstad, A. Subjective health complaints and modern health worries in patients with subjective food hypersensitivity. Dig. Dis. Sci. 2005, 50, 1245-1251. [CrossRef] [PubMed]

74. Montano, D. Supervisor behavior and its associations with employees' health in Europe. Int. Arch. Occup. Environ. Health 2016, 89, 289-298. [CrossRef] [PubMed] 
75. Danna, K.; Griffin, R.W. Health and well-being in the workplace: A review and synthesis of the literature. J. Manag. 1999, 25, 357-384. [CrossRef]

76. Eriksen, H.R.; Ihlebaek, C.; Ursin, H. A scoring system for subjective health complaints (SHC). Scand. J. Public Health 1999, 27, 63-72. [CrossRef]

77. Tellnes, G.; Bjerkedal, T. Epidemiology of Sickness Certification - a Methodological Approach Based on a Study from Buskerud County in Norway. Scand. J. Soc. Med. 1989, 17, 245-251. [CrossRef] [PubMed]

78. Ilmarinen, J.; Tuomi, K. Past, Present and Future of Work Ability; Ilmarinen, J., Lehtinen, S., Eds.; Finnish Institute of Occupational Health: Helsinki, Finland, 2004.

79. Ilmarinen, J.; Tuomi, K.; Seitsamo, J. New dimensions of work ability. Int. Congr. Ser. 2005, 1280, 3-7. [CrossRef]

80. Von Bonsdorff, M.E.; Kokko, K.; Seitsamo, J.; von Bonsdorff, M.B.; Nygård, C.H.; Ilmarinen, J.; Rantanen, T. Work strain in midlife and 28-year work ability trajectories. Scand. J. Work Environ. Health 2011, 37, 455-463. [CrossRef]

81. Palermo, J.; Fuller-Tyszkiewics, M.; Walker, A.; Appannah, A. Primary- and secondary-level organizational predictors of work ability. J. Occup. Health Psychol. 2013, 18, 220-229. [CrossRef]

82. Kujala, V.; Tammelin, T.; Remes, J.; Vammavaara, E.; Ek, E.; Laitinen, J. Work ability index of young employees and their sickness absence during the following year. Scand. J. Work Environ. Health 2006, 32, 75-84. [CrossRef]

83. Nygard, C.H.; Arola, H.; Siukola, A.; Savinainen, M.; Luukkaala, T.; Taskinen, H.; Virtanen, P. Perceived work ability and certified sickness absence among workers in a food industry. Int. Congr. Ser. 2005, 1280, 296-300. [CrossRef]

84. Schouten, L.S.; Joling, C.; van der Gulden, J.W.J.; Heymans, M.W.; Bültmann, U.; Roelen, C.A.M. Screening manual and office workers for risk of long-term sickness absence: cut-off points for the Work Ability Index. Scand. J. Work Environ. Health 2015, 41, 36-42. [CrossRef] [PubMed]

85. Alavinia, S.M.; de Boer, A.G.E.M.; van Duivenbooden, J.C.; Frings-Dresen, M.H.W.; Burdorf, A. Determinants of work ability and its predictive value for disability. Occup. Med. Oxf. 2009, 59, 32-37. [CrossRef] [PubMed]

86. De Wind, A.; Geuskens, G.A.; Ybema, J.F.; Bongers, P.M.; van der Beek, A.J. The role of ability, motivation, and opportunity to work in the transition from work to early retirement - testing and optimizing the Early Retirement Model. Scand. J. Work Environ. Health 2015, 41, 24-35. [CrossRef] [PubMed]

87. Meijman, T.F.; Schaufeli, W. Psychische vermoeidheid en arbeid: Ontwikkelingen in de A\&O psychologie. De Psycholoog 1996, 236-241.

88. Janssen, N.; Kant, I.; Swaen, G.M.H.; Janssen, P.P.M.; Schroer, C.A.P. Fatigue as a predictor of sickness absence: results from the Maastricht cohort study on fatigue at work. Occup. Environ. Med. 2003, 60, 71-76. [CrossRef]

89. Samkoff, J.S.; Jacques, C.H.M. A Review of Studies Concerning Effects of Sleep-Deprivation and Fatigue on Residents Performance. Acad. Med. 1991, 66, 687-693. [CrossRef]

90. Knudsen, H.K.; Ducharme, L.J.; Roman, P.M. Turnover intention and emotional exhaustion "at the top": Adapting the job demands-resources model to leaders of addiction treatment organizations. J. Occup. Health Psychol. 2009, 14, 84-95. [CrossRef]

91. Dohrmann, S.B.; Leppin, A. Determinants of seafarers' fatigue: A systematic revie and quality assessment. Int. Arch. Occup. Environ. Health 2017, 90, 13-37. [CrossRef]

92. Vignoli, M.; Guglielmi, D.; Bonfiglioli, R.; Violante, F.S. How job demands affect absenteeism? The mediating role of work-family conflict and exhaustion. Int. Arch. Occup. Environ. Health 2016, 89, 23-31. [CrossRef]

93. Meijman, T.F. Mentale Belasting en Werkstress, een Arbeidspsychologische Benadering; Van Gorcum: Assen, The Netherlands, 1989.

94. Sluiter, J.K.; Frings-Dresen, M.H.W.; van der Beek, A.J.; Meijman, T.F. The relation between work-induced neuroendocrine reactivity and recovery, subjective need for recovery, and health status. J. Psychosom. Res. 2001, 50, 29-37. [CrossRef]

95. Meijman, T.F. Over Vermoeidheid: Arbeidspsychologische Studies Naar de Beleving van Belastingseffecten; University of Groningen: Groningen, The Netherlands, 1991.

96. Zijlstra, F.R.H.; Cropley, M.; Rydstedt, L.W. From recovery to regulation: an attempt to reconceptualize 'recovery from work'. Stress Health 2014, 30, 244-252. [CrossRef] [PubMed]

97. De Croon, E.M.; Sluiter, J.K.; Frings-Dresen, M.H.W. Need for recovery after work predicts sickness absence-A 2-year prospective cohort study in truck drivers. J. Psychosom. Res. 2003, 55, 331-339. [CrossRef] 
98. De Croon, E.M.; Sluiter, J.K.; Blonk, R.W.B.; Broersen, J.P.J.; Frings-Dresen, M.H.W. Stressful work, psychological job strain, and turnover: A 2-year prospective cohort study of truck drivers. J. Appl. Psychol. 2004, 89, 442-454. [CrossRef] [PubMed]

99. Gommans, F.; Jansen, N.; Stynen, D.; de Grip, A.; Kant, I. The ageing shift worker: a prospective cohort study on need for recovery, disability, and retirement intentions. Scand. J. Work Environ. Health 2015, 41, 356-367. [CrossRef]

100. Mohren, D.C.L.; Jansen, N.W.H.; Kant, I. Need for recovery from work in relation to age: A prospective cohort study. Int. Arch. Occup. Environ. Health 2010, 83, 553-561. [CrossRef]

101. Jansen, N.W.H.; Kant, I.; van den Brandt, P.A. Need for recovery in the working population: Description and associations with fatigue and psychological distress. Int. J. Behav. Med. 2002, 9, 322-340. [CrossRef]

102. Spector, P.E. Job Satisfaction: Application, Assessment, Causes and Consequences; SAGE Publications: Thousand Oaks, CA, USA, 1997.

103. De Jonge, J.; Schaufeli, W.B. Job characteristics and employee well-being: A test of Warr's vitamin model in health care workders using structural equation modelling. J. Organ. Behav. 1998, 19, 387-407. [CrossRef]

104. Harter, J.K.; Schmidt, F.L.; Hayes, T.L. Business-unit-level relationship between employee satisfaction, employee engagement, and business outcomes: A meta-analysis. J. Appl. Psychol. 2002, 87, 268-279. [CrossRef]

105. Latham, G.P. Work Motivation; SAGE Publications: Thousand Oaks, CA, USA, 2012.

106. Duijts, S.F.A.; Kant, I.; Swaen, G.M.H.; van den Brandt, P.A.; Zeegers, M.P.A. A meta-analysis of observational studies identifies predictors of sickness absence. J. Clin. Epidemiol. 2007, 60, 1105-1115. [CrossRef]

107. Nijp, H.H.; Beckers, D.G.J.; Geurts, S.A.E.; Tucker, P.; Kompier, M.A.J. Systematic review on the association between employee worktime control and work-non-work balance, health and well-being, and job-related outcomes. Scand. J. Work Environ. Health 2012, 38, 299-313. [CrossRef]

108. Ryan, R.M.; Deci, E.L. Self-determination theory and the facilitation of intrinsic motivation, social development, and well-being. Am. Psychol. 2000, 55, 68-78. [CrossRef] [PubMed]

109. Gagné, M.; Deci, E.L. Self-determination theory and work motivation. J. Organ. Behav. 2005, 26, 331-362. [CrossRef]

110. Houkes, I.; Janssen, P.P.M.; Jonge, J.; Bakker, A.B. Specific determinants of intrinsic work motivation, emotional exhaustion and turnover intention: a multisample longitudinal study. J. Occup. Organ. Psychol. 2003, 76. [CrossRef]

111. Battistelli, A.; Galletta, M.; Portoghese, I.; Vandenberghe, C. Mindsets of commitment and motivation: interrelationships and contribution to work outcomes. J. Psychol. 2013, 147, 17-48. [CrossRef] [PubMed]

112. Sanders, J.; de Grip, A. Training, task flexibility and the employability of low-skilled workers. Int J. Manpow. 2004, 25, 73-89. [CrossRef]

113. Groot, W.; Maassen van den Brink, H. Education, training and employability. Appl. Econ. 2000, 32, 573-581. [CrossRef]

114. Allen, J.; de Grip, A. Does skill obsolescence increase the risk of employment loss? Appl. Econ. 2012, 44, 3237-3245. [CrossRef]

115. Besen, E.; Pransky, G. Trajectories of productivity loss over a 20-year period: an analysis of the National Longitudinal Survey of Youth. Scand. J. Work Environ. Health 2014, 40, 380-389. [CrossRef]

116. Darr, W.; Johns, G. Work strain, health, and absenteeism: a meta-analysis. J. Occup. Health Psychol. 2008, 13, 293-318. [CrossRef]

117. Bielecky, A.; Chen, C.; Ibrahim, S.; Beaton, D.E.; Mustard, C.A.; Smith, P.M. The impact of co-morbid mental and physical disorders on presenteeism. Scand. J. Work Environ. Health 2015, 41, 554-564. [CrossRef]

118. Mänty, M.; Kouvonen, A.; Lallukka, T.; Lahti, J.; Lahelma, E.; Rahkonen, O. Changes in working conditions and physical health functioning among midlife and ageing employees. Scand. J. Work Environ. Health 2015, 41,511-518. [CrossRef] [PubMed]

119. Gould, R.; Ilmarinen, J.; Järvisalo, J.; Koskinen, S. Dimensions of Work Ability: Results of the Health 2000 Survey; Finnish Centre for Pensions: Helsinki, Finland, 2008.

120. Mohren, D.C.L.; Jansen, N.W.H.; van Amelsvoort, L.G.P.M.; Kant, I.A. Epidemiological Approach of Fatigue and Work: Experiences from the Maastricht Cohort Study; Wilco: Amersfoort, The Netherlands, 2007.

121. Mitchell, T.R.; Daniels, D. Motivation. In Handbook of Psychology; Borman, W.C., Ilgen, D.R., Klimoski, R.J., Eds.; Wiley: New York, NY, USA, 2003; Volume 12, pp. 225-254. 
122. Duncan, T.E.; Duncan, S.C.; Strycker, L.A. An Introduction to Latent Variable Growth Curve Modeling: Concepts Issues and Applications, 2nd ed.; Lawrence Erlbaum Associates: Mahwah, NJ, USA, 2006.

123. McCollum, D. Towards (un)sustainable employment? Exploring policiy responses to work-welfare cycling. Policy Stud. 2012, 33, 215-230. [CrossRef]

124. Secker, J.; Membrey, H. Promoting mental health through employment and developing healthy workplaces: the potential of natural supports at work. Health Educ. Res. 2003, 18, 207-215. [CrossRef] [PubMed]

125. Schuring, M.; Robroek, S.J.W.; Lingsma, H.F.; Burdorf, A. Educational differences in trajectories of self-rated health before, during, and after entering or leaving paid employment in the European workforce. Scand. J. Work Environ. Health 2015, 41, 441-450. [CrossRef]

126. Timming, A.R. The effect of forein accent on employability: a study of the aural dimensions of aesthetic labour in customer-facing and non-customer-facing jobs. Work Employ. Soc. 2016, 1-20. [CrossRef]

127. Renkema, M.; Meijerink, J.; Bondarouk, T. Advancing multilevel thinking in human resource management research: Applications and guidelines. Hum. Resour. Manag. Rev. 2017, 27, 397-415. [CrossRef]

128. Shore, L.M.; Cleveland, J.N.; Sanchez, D. Inclusive workplaces: A review and model. Hum. Resour. Manag. Rev. 2018, 28, 176-189. [CrossRef]

129. Kellard, K.; Walker, R.; Ashworth, K.; Howard, M.; Liu, W.C. Staying in Work: Thinking about a New Policy Agenda; Department for Education and Employment: London, UK, 2001.

130. Koolhaas, W. Sustainable Employability of Ageing Workers; University of Groningen: Groningen, The Netherlands, 2014.

131. Prakash, K.C.; Neupane, S.; Leino-Arjas, P.; von Bonsdorff, M.B.; Rantanen, T.; von Bonsdorff, M.E.; Seitsamo, J.; Ilmarinen, J.; Nygard, C.H. Midlife job profiles and disabilities in later life: a 28-year follow-up of municipal employees in Finland. Int. Arch. Occup. Environ. Health 2016, 89, 997-1007. [CrossRef]

132. Fleuren, B.P.I. Caught somewhere in time: Conceptualizing, measuring, and predicting sustainable employability; Maastricht University: Maastricht, The Netherlands, 2019. [CrossRef]

133. Hackman, J.R.; Oldham, G.R. Motivation through the design of work: test of a theory. Org. Behav. Hum. Perf. 1976, 16, 250-279. [CrossRef]

134. Baba, V.V.; Jamal, M. Routinisation of job context and job content as related to employees quality of working life: a study of psychiatric nurses. J. Organ. Behav. 1991, 12, 379-386. [CrossRef]

135. Taylor, J.C. The quality of working life in Western and Eastern Europe. In Handbook of Work and Organizational Psychology; Cooper, C.L., Mumford, E., Eds.; American Book Publishers: Toronto, ON, Canada, 1979; Volume 2.

136. Mirvis, P.H.; Lawler, E.E. Accounting for the quality of work life. J. Organ. Behav. 1984, 5, 197-212. [CrossRef]

137. Demerouti, E.; Bakker, A.B.; Nachreiner, F.; Schaufeli, W.B. The job demands-resources model of burnout. J. Appl. Psychol. 2001, 86, 499-512. [CrossRef] [PubMed]

138. Dharam, G.H.A.I. Decent work: concept and indicators. Int. Labour Rev. 2003, 142, 113-145. [CrossRef]

139. Hacker, W. Arbeitspsychologie; VEB Deutscher Verlag der Wissenschaften: Berlin, Germany, 1986.

140. Fleuren, B.P.I.; van Amelsvoort, L.G.P.M.; de Grip, A.; Zijlstra, F.R.H.; Kant, I. Time takes us all? A two-wave observational study of age and time effects on sustainable employability. Scand. J. Work Environ. Health 2018, 44, 474-484. [CrossRef] [PubMed]

141. Mohrman, S.A.; Worley, C.G. The organizational sustainability journey: Introduction to the special issue. Organ. Dyn. 2010, 39, 289-294. [CrossRef]

142. App, S.; Merk, J.; Büttgen, M. Employer branding: Sustainable HRM as competitive advantage in the market for high-quality employees. Manag. Rev. 2012, 23, 262-278. [CrossRef]

143. Zink, K.J. Designing sustainable work systems: The need for a systems approach. Appl. Ergon. 2014, 45, 126-132. [CrossRef]

144. Fleuren, B.P.I.; de Grip, A.; Kant, I.; Zijlstra, F.R.H. Time equals money? A randomized controlled field experiment on the effects of four types of training vouchers on training participation. J. Vocat. Behav. 2020, 118. [CrossRef]

(C) 2020 by the authors. Licensee MDPI, Basel, Switzerland. This article is an open access article distributed under the terms and conditions of the Creative Commons Attribution (CC BY) license (http://creativecommons.org/licenses/by/4.0/). 